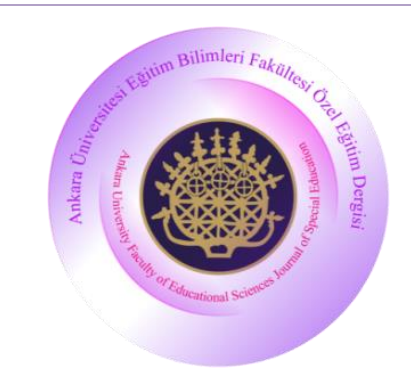

ARAŞTIRMA

\title{
Ankara Üniversitesi Eğitim Bilimleri Fakültesi Özel Eğitim Dergisi
}

Yıl: 2021, Cilt: 22, Sayı: 1, Sayfa No: 113-145

doi: 10.21565/ozelegitimdergisi.621484

\section{Özel Yetenekli Çocukların Kendi Arkadaşlık İlişkilerine Yönelik Görüşleri}

\author{
Fidan Özbey-Gökçe \\ Düzce Üniversitesi
}

\author{
Hadiye Ellibeş-Cerrah ${ }^{(\mathbb{D} *}$ \\ Milli Eğitim Bakanlığı
}

\author{
Şükran Arpaz-Ünsal ${ }_{* * *}$ \\ Milli Ĕ̆itim Bakanlığ
}

Öz

$\mathrm{Bu}$ araştırma özel yetenekli çocukların kendi arkadaşlık ilişkilerine yönelik görüşlerini belirlemeyi amaçlayan nitel bir araştırmadır. Çalışma grubunu Düzce, Bolu ve Samsun illerinde yaşayan özel yetenekli 12 öğrenci oluşturmaktadır. Veriler araştırmacılar tarafından geliştirilen yarı yapılandırılmış Arkadaşlık İlişkileri Görüşme Formu kullanılarak toplanmıştır. Verilerin analizi aşamasında 9 tema oluşturulmuş ve bulgular bu temalar altında düzenlenmiştir. Bu temalar; birliktelik, çatışma, yakınlık, iletişim, yardım, bağlılık, güven, özdeşim ve sadakat temaları olarak sıralanmaktadır. Bulgulara göre; öğrenciler arkadaşlarının evlerine sık sık gidip birlikte zaman geçirdiklerini, onlarla zaman geçirmekten keyif aldıklarını öte yandan yalnız zaman geçirmeyi de sevdiklerini göstermektedir. İyi bir arkadaşta aradıkları en temel özelliğin güven olduğu belirlenmiştir. Arkadaşlarının başarıları ile mutlu olduklarını ve kendi başarıları ile de arkadaşlarının mutlu olduklarını dile getirmişlerdir. Elde edilen bulgular alan yazın çerçevesinde tartışılmıştır. İleri araştırmalarda özel yetenekli öğrencilerin kendi arkadaşlık ilişkilerine yönelik görüşlerine ek olarak akranlarının da “özel yetenekli öğrencinin arkadaşlık ilişkilerine” yönelik görüşleri alınarak iki grup arasında karşılaştırma yapılabilir.

Anahtar sözcükler: Akranlar, arkadaşlık ilişkileri, özel yetenekli çocuk, arkadaş, akran ilişkileri.

\section{Önerilen Atıf Șekli}

Özbey-Gökçe, F., Ellibeş-Cerrah, H., \& Arpaz-Ünsal Ş. (2021). Özel yetenekli çocukların kendi arkadaşlık ilişkilerine yönelik görüşleri. Ankara Üniversitesi Eğitim Bilimleri Fakültesi Özel Ĕgitim Dergisi, 22(1), 113-145. doi: 10.21565/ozelegitimdergisi.621484

\footnotetext{
${ }^{*}$ Sorumlu Yazar: Dr. Öğr. Üyesi, E-posta: fidanozbey@duzce.edu.tr, https://orcid.org/0000-0001-6600-3931

**Öğretmen, E-posta: hadiye55@hotmail.com, https://orcid.org/0000-0003-2933-4859

*** Öğretmen, E-posta: aytenarpaz@ hotmail.com, https://orcid.org/0000-0002-9706-9711
} 
Özel yetenekli çocuklar bir ya da birden fazla alanda beklenenin üstünde performans sergileyen çocuklardır. Akarsu'ya göre (2001) özel yetenekli çocuklar, farklı türden çocuklar değil, bütün çocuklarda bulunan özelliklerin dağı̆ımı, sıklı̆̆ Rimm (2004) de, entelektüel-akademik yetenekler, yaratıcı ve üretici düşünce biçimi, liderlik potansiyeli, sanatsalpsikomotor yeteneklerde üstün bir başarı potansiyeline sahip çocukları "özel yetenekli çocuk" olarak nitelendirmiştir. Özel yetenekli çocuk, kendi akranları ile karşılaştırıldığında en az bir veya daha fazla alanda yüksek performans gösterebilen; ailesinden, akranlarından ve eğitim ortamlarından sosyal/duygusal desteğe gereksinimi olan çocuk olarak tanımlanmaktadır (Lovecky, 1993). Özel yetenekli çocukların akranları ile aralarındaki arkadaşlık ilişkileri, gereksinim duydukları sosyal/duygusal desteğin sağlanması noktasında önemli bir yere sahiptir.

Arkadaşlık, çocuğun gelişim sürecinde önemli bir yeri olan, sosyal, duygusal ve bilişsel gelişim düzeylerine etki eden ve çocuğun uyum sağlamasında önemli rolü olan kritik bir olgudur. Arkadaşlık, karşılıklı ve gönüllü özel bir ilişki türüdür. Karşılıklı olması, her iki tarafın da bu arkadaşlığı tanıması ve sürdürmesi anlamını taşımaktadır (Vasta, Haith, \& Miller, 1992). Bireyin, bütün yaşamında içinde yaşadığı toplumun diğer üyeleriyle girdiği sosyal etkileşimlerde, iletişimi başlatma, sürdürme ve sosyal problemleri çözümleme becerileri kritik önem taşıyan becerilerdir (Shure \& Spivack, 1980; 1982). Bu bağlamda arkadaşlık ilişkileri, bireyler arası sosyal becerilerin ediniminde önemli bir yere sahiptir. Nitekim yürütülen araştırmalar arkadaşlık ilişkilerinin, çocukların bilişsel, duygusal ve sosyal gelişimleri ile çocuğun sosyal uyumunu önemli düzeyde etkilediğini ortaya koymaktadır (Bloomquist \& Schnell, 2002; Little \& Brendgen, 1999; Dodge \& Bickart, 1998; Fergusson, Woodward, \& Horwood, 1999; Heiman, 2000a; Hepler, 1997; Ladd, Kochenderfer, \& Coleman, 1996; Shure, 2001). Çocukların arkadaşları ile kurdukları sosyal diyaloglar, duygusal destek ve paylaşımlar, çocuğun iç dünyasının zenginleşmesine yardımcı olmaktadır. Dahası arkadaşlık ilişkileri, topluma uyum becerilerinin geliştirilmesi suretiyle yeni arkadaşlar edinilmesini kolaylaştırmakta ve toplumsal normların öğrenilmesine de katkıda bulunmaktadır (Hortaçsu, 2002). Arkadaşlık ilişkileri zayıf olan çocuklarda ise tam tersi bir durum yaşanmaktadır. Arkadaşları tarafından ötekileştirilen çocukların, yaşadıkları bu dışlanma durumunun kendi yetersizliklerinden kaynaklandığını düşündükleri ve bu nedenle de birtakım problemler yaşadıkları belirtilmektedir. Arkadaşları ile sosyal ilişki başlatma ve sürdürmede kendini yetersiz görme, özgüven eksikliği ve yalnızlık hissi, depresif ve içe kapanık davranışlar yaşadıkları problemlere örnektir (Bloomquist \& Schnell, 2002; Heiman, 2000b).

Çocukların arkadaş seçiminde en belirleyici kriterin "benzerlik" olduğu vurgulanmaktadır. Bir başka ifade ile çocuklar cinsiyet, yaş, benzer ilgiler ve tercihler, etnik köken açısından kendisine en çok benzeyen akranları ile arkadaşlığı uzun dönemli arkadaşlıklara dönüşmektedir (Vasta, Haith, \& Miller, 1992). Bunun tam tersine "farklılıklar" arkadaş seçiminde en az tercih edilmeye neden olan faktörlerdir. Akranları tarafından farklı algılanan çocukların dışlanmaya maruz kalma ihtimallerinin oldukça yüksek düzeyde olduğu belirtilmektedir. (Burton, 2001; Vasta vd., 1992).

Özel yetenekli çocuklar da akranlarına göre "farklı" gelişim gösteren çocuklardır. Özel yetenekli çocukların arkadaşlık ilişkileri, bu çocukların sahip oldukları özelliklerden etkilenmektedir. Özel yetenekli çocukların özellikleri arasında yer alan "eşzamanlı olmayan gelişim gösterme" özelliği de arkadaşlık ilişkilerini etkileyen faktörler arasındadır (Saranlı, 2017). Örneğin, gelişim alanları açısından incelendiğinde bazı özel yetenekli çocukların bilişsel becerileri oldukça ileri düzeyde olabilirken sosyal-duygusal gelişim ve motor gelişimleri normal gelişim gösteren akranları ile aynı düzeyde veya akranlarından geri düzeyde olabilmektedir. $\mathrm{Bu}$ nedenle bir ya da birkaç gelişim alanında yüksek potansiyele sahip olabilen özel yetenekli çocukların eş zamanlı olmayan gelişimleri sebebiyle sosyal ve duygusal problemler yaşayabildiği belirtilmektedir (Fiedler, 1993; Kearney, 1996). Örneğin; takvim yaş1 5 olan bir çocuk 9 yaş bilişsel özelliklere sahip olabilir. Bu durum ilk bakışta olumlu gibi algılansa da özel yetenekli çocuğun akran ve arkadaşlık ilişkilerini karmaşıklaştırabilmektedir. Takvim yaş1 5 olan fakat 9 yaş bilişsel özelliklerine sahip olan özel yetenekli bir çocuk, oyun oynamak veya etkili zaman geçirmek için genellikle zeka yaşına uygun akranları tercih etmektedir (Levent, 2011). Yani takvim yaşı kendinden 
daha büyük çocuklarla zaman geçirmeyi tercih etmekte ve bu durum yaşıtlarıyla vakit geçirmek istememesine neden olmaktadır. Dolayısıyla yaşıtlarından kaçma davranışı görülebilmektedir. Bu da kendi sınıfındaki akranlarıyla ilişkilerini olumsuz yönde etkileyebilmektedir. Gross (2012), çocukların zeka yaşı mı yoksa takvim yaşında göre mi arkadaş edindiklerini incelemek üzere 5-12 yaş arası 7000 çocukta bir araştırma yapmış, bunun sonucunda normal ve özel yetenekli çocukların arkadaşlık kavramları incelenmiştir. Özel yetenekli çocukların yaşça büyük bireylerle daha iyi anlaştıkları belirlenmiştir. Bu araştırmaya göre aynı yaşlardaki özel yetenekli çocuklar güvenebilecekleri arkadaşlar seçerken, normal gelişim gösteren akranları oyun arkadaşı aramaktadırlar.

Özel yetenekli çocukların kendilerine has gelişimsel özellikleri; onların akranlarıyla bazı sosyal ve duygusal sorunlar yaşamalarına neden olabilmekte (Bainbridge, 2011) fakat yine sahip oldukları özelliklerden biri olan "problem çözme" becerileri sayesinde karşılaştıkları bu sorunlara nitelikli çözümler üretebilmelerini (Çetinkaya, 2014) olanaklı kılmaktadır. Öte yandan özel yetenekli çocukların diğer çocuklardan daha fazla bilgiye sahip olmaları, bildiklerini sözel anlatmaları ve çok soru sormak gibi özellikleri nedeniyle arkadaşlarıyla olan ilişkileri olumsuz etkilenebilmektedir (Koçal vd., 2009).

Ergin (2004), özel yetenekli çocukların zekâ düzeyleri ile iletişim becerileri arasında anlamlı pozitif bir ilişki bulmuştur. Dil ve iletişim becerilerinin güçlü olması, özel yetenekli çocukların akranları ile iletişimlerini olumlu yönde etkilemektedir. Çünkü kişilerarası etkileşimin temelini iletişim becerileri oluşturmaktadır. Günlük yaşamda arkadaşlık iliş̧kileri de iletişim becerilerinden etkilendiğinden, çocuklar sahip oldukları iletişim becerileri sayesinde ilişkilerini düzenleyebilmektedirler. Çocukların arkadaşlarıyla etkin iletişimi başlatma, sürdürme ve bundan doyum elde edebilmeleri için iletişim becerilerine sahip olmaları gerekmektedir (Erigüç, Şener, \& Eriş, 2013). Nitekim üstün bilişsel potansiyele ve özel yeteneklere sahip çocukların akranlarına göre daha erken ve daha ileri düzeyde gelişmiş dil becerilerine sahip oldukları araştırmacılar tarafından belirtilmektedir (Clark, 2002; Ruf, 2009; Sternberg, 1997). Diğer bir araştırmada özel yetenekli çocukların normal gelişim gösteren çocuklara nazaran daha fazla sosyal beceri ve sosyal olgunluğa sahip oldukları belirtilmektedir (Robinson, 2008; Shechtman \& Silektor, 2012). Öte yandan bazı araştırmaların da özel yetenekli çocukların sahip olduğu mükemmeliyetçi tutumun, onları arkadaşlık ilişkilerinde aşırı seçiciliğe yöneltebildiği ve sonuç olarak özel yetenekli çocukların akranları ile iletişim sorunu yaşamalarına sebep olabildiğini göstermektedir (Karakuş, 2010).

Arkadaşlar tarafından kabul görme, bir grubun üyesi olma ve sevgi ihtiyacı, Maslow'un belirttiği beş temel ihtiyaçtan birisidir (Sağlam, 2011). Arkadaşlık ilişkileri, ilk çocukluk yıllarından başlayarak çeşitli şekillerde ergenliğin sonuna kadar bireylerin yaşamlarında, duygusal ve sosyal gelişimlerinde son derece önemli bir yere sahiptir. Arkadaşlık ilişkileri, aynı yaşta veya aynı gelişim düzeyinde benzer geçmiş yaşantılar, değerler, benzer yaşam tarzları ve benzer sosyal bağlamı paylaşan bireyler arasında hem karşılıklılık hem de devam eden etkileşimler bütünü olarak tanımlanmaktadır (Gülay, 2009). Uzun yıllardır yapılan çalışmalar, arkadaşlık ilişkilerinin çocukların sosyo-psikolojik gelişimleri açısından öneminin büyük olduğunu ortaya koymaktadır (Gülay, 2010). Olumlu arkadaşlık ilişkileri, çocuğu sosyal yaşama hazırlamaktadır. Ayrıca yaşanılan toplumun dinamiklerini öğrenme ve buna uygun davranış kalıpları geliştirmede arkadaşlar yol gösterici olabilmektedir (Köse, 2015). Arkadaşların çocuğun tutum ve davranışları üzerindeki etkisi, yaşları büyüdükçe artmakta ve ergenlik çağında zirveye ulaşmaktadır (Delikara, 2002).

Özel yetenekli çocukların arkadaşlık ilişkilerinden beklentileri normal gelişim gösteren akranlarına göre bazı farklılıklar gösterebilmektedir (Gross, 2002). Bu tür çocuklar, sahip oldukları özellikler nedeniyle genel olarak okulda ya da akran grupları içerisinde popüler çocuklardır. Çoğu zaman akranlar tarafından kolay kabul görürler ve liderlik özelliklerine sahiptirler. Ancak ilgi alanlarının farklılıkları ya da eşzamanlı olmayan gelişimleri nedeniyle yalnızlığı tercih ettikleri de sık görülmektedir. Özel yetenekli çocuklar bir veya birkaç gelişim alanında çok iyi düzeyde becerilere sahip olabilirlerken sosyal iletişim, sanat ya da psikomotor becerilerde akranları ile benzer, hatta bazen akranlarından daha geri düzeyde gelişim gösterebilmektedirler (Dağlığlu, 2010). Tüm bu özellikler, özel yetenekli çocukların akranlarıyla kurdukları ilişkileri de etkilemektedir. Sonuç olarak akranları ile olumlu ve yakın arkadaşlıklar kurmak onlar için zorlaşabilmektedir (Kline \& Meckstroth, 1985). Bu yüzden birçok özel yetenekli çocuk arkadaş edinmekte sıkıntı çekebilmektedir (Webb, 1994; Winner, 1996). Bazı özel yetenekli 
çocuklar arkadaşlarının kendisini kabul etmesi ve sosyal çevrelerine dahil etmeleri için sahip oldukları yeteneklerini ve farklı ilgilerini gizlemeye çalışmakta, onlar gibi görünme çabası içine girebilmekte ve bu yolla yalnız kalmanın önüne geçmeye çalışmaktadırlar. Bazılarıysa arkadaş edinebilmek adına bir çıkış noktası bulamadığı için yalnız kalmaktadır (Smutny, 2001).

Özel yetenekli çocukların arkadaşlık ilişkilerinde karşılaştıkları sorunlar arasında; yeni bir arkadaş edinme güçlüğü, alay edilme, korku, anksiyete, endişeler ve aşırı mükemmeliyetçilik gibi problemler yer almaktadır. Bu tür sorunlar özel yetenekli çocukların eğitim yaşantısından uzaklaşmak istemelerine ve ileride toplumsal sorunlar yaşamalarına neden olabilmektedir. Sosyal-duygusal problemler çocuk için akademik başarısızlıktan daha ciddi sorunlara yol açabilmektedir (Gür, 2011). Özel yetenekli çocukların akranlarına göre yüksek oranda anksiyete yaşadığı ve depresif duygu durum belirtilerini sergiledikleri yapılan çalışmalarda bulunmuştur (Hewitt, Caelian, Flett, Sherry, Collins, \& Flynn, 2002; Yoo \& Moon, 2006) Çocukların yaşadığı yoğun stresin nedeni sıklıkla aile ve arkadaşlık ilişkilerinde yaşanan güçlükler, ulaşılması zor hedefler (Dixon, Lapsley, \& Hanchon, 2004), ebeveynlerin yüksek beklenti içinde olması ve eleştirel tutum sergilemesi (Enns, Cox, \& Clara, 2002; Kawamura, Frost, \& Harmatz, 2002) akademik baskılardır (Peterson, Duncan, \& Canady, 2009).

Karakuş (2010) özel yetenekli çocuğa sahip ailelerin karşılaştıkları başlıca sorunlar arasında çocukların akranları tarafından dışlanması ve akranları ile arkadaşlık kuramama sorunlarını dile getirdiklerini belirtmektedir. Özel yetenekli çocukların sahip oldukları "mükemmeliyetçilik" ve "arkadaş ilişkilerinde seçicilik" gibi nitelikleri nedeni ile sınıf arkadaşları ile iletişimde çatışma yaşadıkları belirtilmiştir. Mükemmelliyetçilik, üst düzey niteliklerde olmayan, yani mükemmel olarak nitelendirilemeyecek hiçbir şeyden mutlu olamamak anlamına gelmektedir (Büyükbayraktar, 2011). Özel yetenekli çocuklarda oldukça sık görülen özelliklerden biridir. Mükemmeliyetçi yapıları sebebiyle çocuklar sorumluluklarını noksansız bir şekilde gerçekleştirmek için büyük çaba sarf ederlerken çevrelerindeki diğer bireylerin de hatasız olmalarını istemektedirler. Kendilerine karşı yapılan hataları da müsamaha gösterememektedirler. Kendileri hata yaptıkları zaman ise bunu derhal fark etmekte ve düzeltebilmektedirler (Çağlar, 2004). Fakat mükemmeliyetçiliğin sonucu olarak ortaya çıkan mükemmel olma kaygısı, çocuklarda suçluluk duygusuna neden olabilmekte ve onların yeni keşifler yapmalarına ve yeni insanlarla tanışmalarına da engel teşkil edebilmektedir. Üstelik özel yetenekli çocuklarda sık görülen mükemmeliyetçi tutum, arkadaşlık ilişkilerinde aşırı seçiciliğe yöneltebilmekte ve özel yetenekli çocukların sosyal etkileşim sorunu yaşamalarına neden olabilmektedir (Karakuş, 2010). Öte yandan yetenekli öğrencilerin arkadaşları ile sosyal uyumları konusunda sorun yaşamadıklarını hatta normal gelişim gösteren çocuklardan daha uyumlu bir sosyal ilişki içerisine girebildiklerini savunan araştırma bulgularına da rastlamak mümkün. Nail ve Evans (1997), kişilik ve davranış değerlendirme (Behavioral Assessment System for Children) ölçeklerini kullanarak 115 özel yetenekli öğrenci ile 97 normal gelişim gösteren öğrenciyi incelemiştir. Buna göre, iki grup arasındaki önemli farklılıklardan birisi özel yetenekli öğrencilerin daha az sosyal uyum problemi yaşamalarıdır. Neihart (1999) tarafından yapılan başka bir araştırma sonucu da özel yetenekli öğrencilerin genel olarak en azından diğer çocuklar kadar uyumlu olduğunu ortaya koymuştur. Erdem'in (2013) yürüttüğü araştırmanın bulgularına göre özel yetenekli çocukların akranları ile birlikte dışarıda vakit geçirme oranı \%82'dir. Dışarıda birlikte yaptıkları aktivitelerin başlıcaları ise; sohbet etmek, sinemaya gitmek, ders çalışmak ve spor yapmak olarak sıralanmıştır. Masden, Leung, Shore, Schneider ve Udvari (2015) tarafından yürütülen bir araştırmada özel yetenekli ergenlerin akademik yetenekleri, sosyal koordinasyonları ve dostluk kalitesi arasındaki ilişki incelenmiştir. Araştırmaya 81'i özel yetenekli toplam 120 tane ergenlik dönemindeki birey katılmıştır. Özel yetenekli olmak ile yüksek arkadaşlık kalitesi arasında önemli ölçüde bir ilişki bulunmuştur. Özel yetenekli öğrencilerin kendi görüşlerine dayalı olarak akranları ile ilişkilerini inceleyen bir araştırmada ise Kerr (1985) özel yetenekli öğrencilerin kendi kişisel gelişim özellikleri ve akademik yeterliklerini olumlu değerlendirirken, sosyal ilişkiler ve akran ilişkileri açısından kendilerini olumsuz gördüklerini ortaya koymuştur.

Özel yetenekli öğrencilerin arkadaşlık ilişkileri onların eğitim ortamları ve de topluma katılımları, sosyal entegrasyonları gibi pek çok açıdan önemli olmakla birlikte bu konuda kendilerini nasıl değerlendirdiklerine yönelik görüşlerin ele alındığı araştırmaların çok sınırlı düzeyde yapılmış olması bu araştırmanın gereğini ortaya 
koymaktadır. Özel yetenekli öğrencilerin kendi arkadaşlık ilişkilerine dair görüşlerinin belirlenmesiyle hem ileri araştırmalara dair yeni pencerelerin aralanması umulmakta; hem de ileri saha uygulamalarına 1ş1k tutulabileceği düşünülmektedir. Bu nedenle bu araştırmada Düzce, Bolu ve Samsun illerinde eğitimlerine devam eden, özel yetenekli çocukların kendi arkadaşlık ilişkilerine yönelik görüşleri incelenmiştir. Bu doğrultuda aşağıdaki alt sorulara yanıt aranmıştır.

1. Özel yetenekli çocuklar kendi arkadaşlık ilişkilerini nasıl değerlendirmektedir?

2. Özel yetenekli çocuklar kendi arkadaşlık ilişkilerinde; birliktelik, çatışma, yakınlık, iletişim, yardım, bağlılık, güven, özdeşim ve sadakat olgularını nasıl değerlendirmektedir?

\section{Yöntem}

\section{Araştırmanın Modeli}

$\mathrm{Bu}$ araştırmada insanların bireysel tecrübelerine nasıl anlam yüklediklerini incelemek, bu anlamlandırmanın doğasına odaklanmak (Patton, 2002) amaçlandığı için nitel araştırma desenlerinden fenomenoloji deseni benimsenmiştir. Fenomenoloji, insanların kendi deneyimlerini nasıl anlayabilecekleri ve inceleyebileceklerine ilişkin zengin fikirler sağlar (Smith, Flowers, \& Larkin, 2009). Moustakas'a (1994) göre fenomenolojide fenomene ilişkin neler deneyimlendiği ve bu fenomene ilişkin deneyimlenen olay ve olguların hangi bağlam ya da durumlardan etkilendiği araştırılır (akt., Cresswell, 2007). Bu araştırmada ise özel yetenekli çocukların kendi arkadaşlık ilişkilerine yönelik görüşlerinin belirlenmesi amaçlanmıştır. Bir diğer ifadeyle, özel yetenekli çocukların kendi arkadaşlık ilişkilerini nasıl anlamlandırdıkları ve arkadaşlık sürecini nasıl algıladıklarını incelemek amaçlandığından fenomenoloji deseni kullanılmıştır.

\section{Çalışma Grubu}

Bu araştırmada veriler; Düzce, Bolu ve Samsun illerinde yaşayan özel yetenekli çocuklardan toplanmıştır. Çocukların seçiminde kolay ulaşılabilir durum örneklemesi kullanılmıştır. Kolay ulaşılabilir durum örneklemesi yönteminde araştırmac1/araştırmacılar kendisine yakın olan ve kolay erişebileceği örnekleri seçtiği için bu yöntem araştırma sürecine hız ve pratiklik kazandırmaktadır (Yıldırım \& Şimşek, 2006, s.112). Etik nedenlerle katılımcıların her biri için birer kod isim belirlenmiş, gerçek isimleri kullanılmamıştır. Kolay ulaşılabilir durum örneklemesi yöntemi ile seçilen çocuklara yönelik bilgiler Tablo 1'de yer almaktadır.

Tablo 1

Katılımcı Bilgileri

\begin{tabular}{lcccccc}
\hline Kod isim & Yaş & Sinıf & Cinsiyet & İl & Tanı & Görüşme süresi \\
\hline Z.K & 7 & 1 & Kiz & Bolu & Özel yetenek & $9 \mathrm{dk}$. \\
R.N.E & 8 & 2 & Kiz & Bolu & Özel yetenek & $21 \mathrm{dk}$. \\
A.K.S & 8 & 2 & Erkek & Bolu & Özel yetenek & $18 \mathrm{dk}$. \\
E.K & 10 & 4 & Kiz & Samsun & Özel yetenek & $20 \mathrm{dk}$. \\
G.Ü & 11 & 5 & Kiz & Samsun & Özel yetenek & $23 \mathrm{dk}$. \\
K.U & 11 & 6 & Erkek & Samsun & Özel yetenek & $19 \mathrm{dk}$. \\
H.S.C & 11 & 6 & Erkek & Samsun & Özel yetenek & $24 \mathrm{dk}$. \\
A.C.G & 12 & 6 & Erkek & Düzce & Özel yetenek & $15 \mathrm{dk}$. \\
A.A.L & 12 & 7 & Erkek & Düzce & Özel yetenek & $14 \mathrm{dk}$. \\
A.S & 13 & 7 & Erkek & Düzce & Özel yetenek & $16 \mathrm{dk}$. \\
B.İ.S & 13 & 7 & Erkek & Düzce & Özel yetenek & $19 \mathrm{dk}$. \\
A.G & 13 & 7 & Erkek & Düzce & Özel yetenek & $18 \mathrm{dk}$. \\
\hline
\end{tabular}

Tablo 1'de görüldüğü gibi araştırma kapsamında toplanan veriler, 2018-2019 eğitim öğretim yılında Samsun, Bolu ve Düzce illerinde öğrenim gören özel yetenekli olarak tanılanmış 12 öğrenciden elde edilmiştir. Araştırmada mecburi ilköğretim çağındaki çocuklarla çalışılması hedeflendiği için katılımcıların farklı sınıf ve yaş düzeyinde olmasına dikkat edilmiştir. Veri toplamaya başlamadan önce ilgili okullar ile iletişime geçilmiştir. 
Araştırmanın amacı, süreci, kullanılacak olan yöntem gibi konularda okul idarelerine bilgi verilmiştir. Okul idareleri çalışmayı yazılı olarak onayladıktan sonra, çalışmaya katılması düşünülen öğrencilerin ailelerine çalışmayla ilgili ayrıntılı bilgilendirme yapılmıştır. 12 aileye izin belgesi gönderilmiştir. Ailelerin tümü çocuklarının çalışmaya katılmasına izin vermiştir. Özel yetenekli tanısı alan çocuklardan 2 tanesi özel bir hastanede tanılanmış olup; diğerleri Rehberlik Araştırma Merkezleri (RAM) tarafından tanılanmışlardır. RAM'da tanılaması yapılan öğrencilerden biri öğrenci görsel sanatlar alanında diğerleri genel yetenek alanında tanılanmışlardır.

\section{Veri Toplama Aracı}

Nitel araştırmalarda gözlem, görüşme ve doküman incelemesi olmak üzere üç temel veri toplama tekniği kullanılmaktadır (Seggie \& Bayyurt, 2015). Bu araştırmada nitel veri toplama tekniklerinden "görüşme tekniği" kullanılmıştır. Görüşme tekniği, araştırmacı ile görüşülen kişi arasında geçen kontrollü ve amaçlı bir sözel iletişim biçimidir (Cotien \& Manion, 1994). Türnüklü (2000) görüşme tekniğinde araştırmanın amacını; görüşülen kişiye araştırma konusuyla ilgili birtakım sorular yöneltmek suretiyle o kişinin kendi duygu ve düşüncelerini sistematik olarak belirlemek, anlamak ve tanımlamaktır şeklinde ifade etmiştir.

Araştırmacılar tarafından ilgili alan yazın incelemesinden sonra araştırmanın amacına uygun olarak yarı yapılandırılmış Arkadaşlık İlişkileri Görüşme Formu hazırlanmıştır. Form hazırlanma aşamasında özel eğitim alanında çalışmakta olan 2 alan uzmanının incelemesi sağlanmış, onların görüşleri doğrultusunda anlaşılmayan ifadeler yeniden düzenlenmiştir. Bu formda arkadaşları ile birlikte vakit geçirmeye yönelik alt soruların yer aldığı "Birliktelik Olgusu”; arkadaşlarıyla çatışma durumlarına yönelik soruların yer aldığı "çatışma olgusu”; arkadaşlarıyla yakınlık durumlarına yönelik soruların yer aldığı "yakınlık olgusu”; arkadaşlarıyla iletişim durumlarına yönelik soruların yer aldığı "iletişim olgusu”; arkadaşlarıyla yardımlaşma durumlarına yönelik soruların yer aldığı "yardımlaşma olgusu”; arkadaşlarına bağlılık durumlarına yönelik soruların yer aldığı "bağlllık olgusu”; arkadaşlarına yönelik güven durumları ile ilgili soruların yer aldı̆̆ı "güven olgusu”; arkadaşlarıyla özdeşim durumlarına yönelik soruların yer aldığı “özdeşim olgusu” ve arkadaşlarıyla sadakat durumlarına yönelik soruların yer aldığı "sadakat olgusu”; olmak üzere 9 temel soru başlığı altında sonda sorular yer almaktadır. Bu sorular "Bulgular" başlığ 1 altındaki tablolarda yer almaktadır.

\section{Verilerin Toplanması}

Arkadaşlık İlişkileri Görüşme Formu, okul içinde çok fazla uyaranın olmadığı ortamlarda öğrencilere bireysel olarak uygulanmıştır. Düzce ve Bolu ilinde gerçekleştirilen görüşmeler birinci yazar tarafından, Samsun ilinde gerçekleştirilen görüşmeler ise ikinci yazar tarafından gerçekleştirilmiştir. Uygulama esnasında öğrencilerin kendilerini rahat hissedecekleri bir ortam sağlanmaya çalışılmıştır. Böylelikle öğrencilerin fikir ve duygularını içtenlikle ortaya koyabilecekleri düşünülmüştür. Olası veri kaybını önlemek adına görüşme esnasında öğrencilerin ses kayıtları alınmıştır. Öğrencilere görüşmeden önce ses kaydı alınacağı belirtilmiştir. İsterlerse görüşme sonunda ses kayıtlarını dinleyebilecekleri ve istedikleri bölümlerin çıkarılabileceği belirtilmiştir. Böylelikle ses kayıtlarının öğrenciler üzerindeki olumsuz etkileri önlenmeye çalışılmıştır. Ses kayıtlarının daha sonra araştırmacılar tarafından Word ortamında dökümleri yapılmıştır. Görüşmeler 2019 yılı Nisan ayının son iki haftası sürecinde gerçekleştirilmiş olup en uzun süren görüşme $21 \mathrm{dk}$, en kısa süren görüşme ise $13 \mathrm{dk}$. sürmüştür.

\section{Verilerin Analizi}

Miles ve Huberman (1984) nitel veri analizi sürecini, ardışık üç evreden oluşan bir sınıflandırma kapsamında ele almaktadır. İlk evrede görüşme, gözlem ve doküman incelemesi gibi çeşitli veri toplama teknikleri yardımı ile toplanan "verilerin azaltılması" evresidir. Bu evrede toplanmış olan ve henüz ham halde bulunan işlenmemiş veri seti eleme, özetleme ve dönüştürme işlemlerinden geçirilmektedir. Aslında verilerin azaltıldığı süreç, araştırma raporunun oluşturulmasına kadar süren uzun bir süreci kapsamaktadır. Bu süreçte araştırmacı, yürüttüğü çalışmanın kapsamına göre hangi verileri araştırmanın kapsamı dışında bırakacağına, hangi verileri araştırma kapsamına alacağına ve toplanan veri setini nasıl bir sınıflandırmaya tabi tutacağına karar vermektedir. 
Bu araştırmada araştırmacılar tarafından dökümü yapılan veriler, ilgili alan yazın çerçevesinde (Kaner, 1998; Atik, Çoban, Çok, Doğan, \& Karaman, 2014) önceden oluşturulan temalar altında birleştirilmiştir. Daha sonra araştırma soruları doğrultusunda bazı veriler kapsam dışında bırakılarak azaltılma yoluna gidilmiştir. Bir başka ifade ile araştırma sorularına yanıt teşkil etmeyecek nitelikteki veriler araştırma kapsamı dışında bırakılmıştır. Bir başka ifade ile öğrencilerin sorulan sorular ile ilgili olmayan yanıtları araştırma kapsamı dışında bırakılmıştır. Örneğin "hatalı olduğun zaman özür diler misin?” sorusuna öğrencinin “biz ailecek teknolojiye düşkünüz” şeklinde verdiği yanıt kapsam dişı bırakılmıştır.

Veri analizinin ikinci evresini "verilerin görsel hale getirilmesi” süreci oluşturmaktadır. Bu evrede ayıklanan, özetlenen ve dönüştürülen verilerin belli bir sonuca ulaşmaya dönük bir şekilde örüntülenmesi amaçlanmaktadır. Bu şekilde henüz belirli bir anlam taşımayan veri seti, verilerin örüntülenmesiyle birlikte daha anlaşılır bir biçime dönüştürülmektedir. Miles ve Huberman (1984) verilerin görsel hale getirilmesi sürecinde matrisler, grafikler ve tablolar kullanılmasını önermektedirler. Peki siz bunlardan hangisini tercih ettiniz? Burada ifade edilmelidir.

Veri analiz sürecinin son basamağını ise "sonuca ulaşma ve teyit etme" oluşturmaktadır. Araştırmacı bu son evrede sürecin en başından itibaren her aşamada topladığı verilerin ne anlama geldiğini anlamaya çalışmaktadır. Araştırma sürecinin en başında belirgin olmayan hatta bir bakıma verilerin içinde saklanmış olan gerçeklik son evrede keşfedilmekte ve gün yüzüne çıkarılmaktadır. Bu araştırmada verilerin analizi sonucunda 9 tema oluşturulmuş ve bulgular bu temalar altında düzenlenmiştir. Bu temalar; birliktelik, çatışma, yakınlık, iletişim, yardım, bağlılık, güven, özdeşim ve sadakat temaları olarak sıralanmaktadır.

Nitel araştırmalarda güvenirlik verileri birden fazla araştırmacı tarafından oluşturulan kodlar arasındaki kararlılık olarak belirtilmektedir (Creswell, 2013). Yazılı metin haline getirilen görüşme dosyaları birinci ve ikinci yazar tarafından bağımsız olarak ayrı ayrı kodlanmış ve kategoriler oluşturulmuştur. Yazarlardan ilki özel eğitim alanında doktora derecesine sahip öğretim üyesi; diğeri ise özel eğitim alnında yüksek lisans öğrencisi olup, yüksek lisans dersleri kapsamında nitel araştırmalar dersini almıştır. Her iki yazar tarafından oluşturulan kodlar incelenerek uygun kategoriler altına yerleştirilmiştir. Oluşturulan kod ve temaların güvenirliği için kodlayıcı güvenirliğine bakılmıştır. Bu kapsamda kodlayıcılar arası güvenirlik puanı görüş birliğine varılan kodlamaların, görüş birliğine varılan ve varılmayan kodlamaların toplamına oranı şeklinde hesaplanmıştır (Miles \& Huberman 1984). İki bağımsız araştırmacı tarafından oluşturulan kod ve kategoriler karşılaştırılmış ve kodlayıcılar arası güvenirlik puanı \%82 olarak bulunmuştur.

\section{Bulgular}

Özel yetenekli çocukların kendi arkadaşlık ilişkilerine yönelik görüşlerinin incelendiği bu araştırmada elde edilen bulgular; birliktelik, çatışma, yakınlık, iletişim, yardım, bağlılık, güven, özdeşim ve sadakat temaları altında düzenlenmiştir. Dolayısıyla bulgular bu temalardan oluşan başlıklar altında yer almaktadır.

\section{Birliktelik}

Çalışma grubunda yer alan öğrencilere "birliktelik" olgusu çerçevesinde yöneltilen sorulara öğrencilerin verdiği yanıtlar ve frekansları Tablo 2'de yer almaktadır.

Tablo 2

Birliktelik Olgusuna İlişkin Sorular ve Öğrenci Yanıtları

\begin{tabular}{|c|c|c|c|}
\hline Sorular & Cevaplar & $f$ & $\%$ \\
\hline \multirow{3}{*}{$\begin{array}{l}\text { Okul çıkışları ve hafta sonları arkadaşlarının } \\
\text { evine gider misin? Onlar senin evine gelir mi? }\end{array}$} & Evet giderim. Mutlu eder. & 5 & 41 \\
\hline & Hayır gitmem, gelmezler. & 4 & 33 \\
\hline & Ara sira giderim, gelirler. & 3 & 25 \\
\hline \multirow{3}{*}{$\begin{array}{l}\text { Arkadaşlarınla boş zamanlarında görüşür } \\
\text { müsünüz? }\end{array}$} & Evet görüşürüz. & 8 & 66 \\
\hline & Hayır görüşmeyiz. & 3 & 25 \\
\hline & Nadiren. & 1 & 8 \\
\hline
\end{tabular}


Tablo 2 (devam)

\begin{tabular}{lccc}
\hline Sorular & Cevaplar & $f$ & $\%$ \\
\hline Arkadaşlarınla yapabileceğin eğlenceli şeyler & Evet, düşünürüz. & 9 & 75 \\
düşünür müsünüz? & Hayır. & 1 & 8 \\
& Bazen. & 1 & 8 \\
& Mutlu hissederim. & 6 & 50 \\
Arkadaşlarınla birlikteyken kendini nasıl & Eğlenceli hissederim. & 1 & 8 \\
hissedersin? & Bazen iyi bazen kötü hissederim. & 1 & 8 \\
& Güvende hissederim. & 2 & 17 \\
& İyi hissederim. & 1 & 8 \\
Yalnız vakit geçirmekten hoşlanır mısın? & Evet hoşlanırım. & 6 & 50 \\
& Hayır hoşlanmam. & 3 & 25 \\
& Bazen. & 3 & 25 \\
\hline
\end{tabular}

Tablo 2'de görüldüğü gibi, araştırmada yer alan öğrencilerin çoğu okul çıkışı arkadaşlarının evine gittiklerini ve bu sebepten dolayı mutlu olduklarını vurgulamışlardır. Verilen yanıtlara bakıldığında özel yetenekli öğrencilerin çoğunluğunun arkadaşlarının evine gittiği, arkadaşlarını evlerine davet ettiği ve bundan mutluluk duydukları görülmektedir. Öğrencilerden E.K görüşlerini "Yani cuma akşamları çok gitmişliğim var da hafta sonları daha çok restoranlarda buluşuyoruz. Onlar da benim evime gelirler. Oyun oynarı, yemek yeriz, tv izleriz. Bu beni mutlu eder. En sevdiklerimden biri de evdeki kupaları dağıtmak." biçiminde ifade etmiştir.

“Arkadaşlarınla yapabileceğin eğlenceli şeyler düşünür müsünüz?” sorusuna yönelik olarak öğrencilerin çoğunluğunun arkadaşlarıyla yapabileceği eğlenceli şeyler düşündüğü görülmektedir. Öğrencilerden A.A.L, görüşlerini "Liderlik ettiğim zamanlar da olur. Bilmiyorum, bir şeyler üretirim aslında." şeklinde ifade etmiştir. Öğrencilerden G.Ü. ise görüşlerini "Yani şu an beşinci sınıfta olduğumuz için hep birlikte sinemaya gitmeyi falan düşünmedik hiç.” şeklinde ifade etmiştir.

\section{Çatıșma Teması}

Çalışma grubunda yer alan öğrencilere "çatışma" olgusu çerçevesinde yöneltilen sorulara öğrencilerin verdiği yanıtlar ve frekansları Tablo 3 'de yer almaktadır.

Tablo 3

Çatışma Olgusuna İlişkin Sorular ve Öğrenci Yanıtları

\begin{tabular}{lccc}
\hline Sorular & Cevaplar & $f$ & $\%$ \\
\hline Arkadaşının sana yaptı̆̆ bir hataya karşı nasıl bir tepki & Hayı̈ söylemem. & 8 & 65 \\
verirsin? Hiddete kapılıp düşüncesiz sözler söyler misin? & Evet söyleyebilirim. & 4 & 33 \\
& Evet ederim. & 4 & 33 \\
Arkadaşlarınla kavga eder misin? & Bazen ederim. & 5 & 42 \\
& Hayır etmem. & 3 & 33 \\
Arkadaşınla kavga edersen, hatalı olduğunda özür diler misin? & Evet dilerim. & 12 & 100 \\
Arkadaşın seni rahatsız eden bir davranışta bulunduğunda nasıl & Uyararak tepkimi belli ederim. & 11 & 91 \\
bir tepki verirsin? & Hiçbir şey demem. & 1 & 8 \\
& Uyarırım. & 5 & 42 \\
Arkadaşın yapmamasını söylediğin bir konuyla ilgili, aynı & Sinirlenirim. & 4 & 33 \\
hatayı tekrar yaparsa nasıl bir tepki verirsin? & Konuşmam. & 1 & 8 \\
& Güvenim kalmaz. & 1 & 8 \\
\hline
\end{tabular}

Araștırmada yer alan öğrencilere "Arkadaşının sana yaptığı bir hataya karşı nasıl bir tepki verirsin? Hiddete kapılıp düşüncesiz sözler söyler misin?” sorusu sorulduğunda öğrencilerin çoğunluğu arkadaşlarına düşüncesiz sözler söylemeyeceğini ifade etmiştir. Diğer dört öğrenci ise hiddete kapılıp kötü sözler 
söyleyebileceklerini belirtmişlerdir. Yanıtlara bakıldığında özel yetenekli öğrencilerin çoğunluğunun kontrollü davranarak, arkadaşı kendine hata bile yapsa hiddete kapılıp kötü sözler söylemediği görülmektedir. Öğrencilerden E.K. “Onu uyarırım, bir daha yapmaması gerektiğini söylerim. Bir daha olursa ilişkilerimizin bozulabileceğini söylerim. Ĕger yaptı̆̆ ç̧ok kötü bir şeyse maalesef kendime engel olmayıp hiddete kapılabilirim. Ama o da çok az, yani engel olamamam." şeklinde duygularını ifade etmiştir. A.S. ise duygularını "Hayır öfkelensem bile içimde yaşarım. O öfkeyi başka yerlerde atarım. Yalnız kalmak isterim mesela. ” şeklinde belirtmiştir.

Öğrencilere, “Arkadaşlarınla kavga eder misin?” sorusu sorulduğunda öğrencilerin dördü arkadaşlarıyla kavga ettiklerini, beşi bazen kavga ettiklerini vurgularken, üçü hiç kavga etmediğini belirtmiştir. Öğrencilerden K.U. bu soru hakkındaki görüşlerini "Samimi arkadaşlar her zaman kavga eder. Mesela H. 'in gözlügünü takmıştım. Ona, 'oğlum alınma ama sen körsün.' dedim. Kavga ettik ve küstük ve sonra barıştık.” şeklinde belirtmiştir.

“Arkadaşın seni rahatsız eden bir davranışta bulundu. Nasıl bir tepki verirsin?” sorusu sorulduğunda öğrencilerin çoğunluğu kendilerini rahatsız eden bir davranışa maruz kaldıklarında tepkilerini arkadaşlarına belli ettiklerini ifade etmişlerdir. Sadece bir öğrenci tepkisiz kaldığını belirtmiştir. R.N.E duygularını "Öncelikle ona, yaptı̆̆ını tekrarlamasının çok kötü bir şey olduğunu söylerim ve sonra hoşgörü ile karşılarım." şeklinde ifade ederken, Z.K ise "Kızarım, sinirlenirim hiçbir şey demem." şeklinde ifade etmiştir.

\section{Yakınlık Teması}

Çalışma grubunda yer alan öğrencilere "yakınlık" olgusu çerçevesinde yöneltilen sorulara öğrencilerin verdiği yanıtlar ve frekansları Tablo 4'de yer almaktadır.

Tablo 4

Yakınlık Olgusuna İlişkin Sorular ve Öğrenci Yanıtları

\begin{tabular}{lccc}
\hline Sorular & Cevaplar & $f$ & $\%$ \\
\hline Kendi fikir ve inançlarının yanında, arkadaşlarının fikirleri & Önem taşır. & 11 & 91 \\
senin için nasıl bir önem taşır? & Orta önem taşır. & 1 & 8 \\
Sevdiğin arkadaşların etrafında yokken onları düşünür müsün? & Evet düşünürüm. & 11 & 91 \\
& Düşünmeye vaktim olmaz. & 1 & 8 \\
Arkadaşın senin için özel bir şey yaptığında mutlu olur musun? & Evet olurum. & 12 & 100 \\
& Güven vermesi. & 6 & 50 \\
İyi bir arkadaşta aradığın özellikler neler? & Çalışkan olması. & 3 & 25 \\
& Dürüst olması. & 1 & 8 \\
& Saygılı olması. & 1 & 8 \\
\hline
\end{tabular}

Araştırmaya katılan öğrencilere, "Kendi fikir ve inançlarının yanında, arkadaşlarının fikirleri senin için nasıl bir önem taşır?" sorusu sorulduğunda öğrencilerin çoğunluğu arkadaşının fikrinin onun için önemli olduğunu belirtmiştir. Sadece bir öğrenci orta derecede önemli olduğunu vurgulamıştır. Verilen yanıtlara bakıldığında özel yetenekli öğrencilerin çoğunluğunun arkadaşlarının fikirlerine önem verdikleri görülmektedir. Öğrencilerden R.N.E "Orta önem taşır" şeklinde düşüncelerini belirtirken, E.K ise "Çok önem taşır. Mesela arkadaşımın fikri benimkinden daha iyiyse eğer o fikir üzerinden çalışırım." şeklinde yanıt vermiştir.

Öğrencilere “İyi bir arkadaşta aradığın özellikler neler?” sorusu sorulduğunda öğrencilerden çoğunluğu iyi bir arkadaşta olması gereken en önemli özelliğin güven duygusu olduğunu ifade etmiştir. Diğer üç öğrenci çalışkanlığı tercih ederken, geriye kalan iki öğrenci ise dürüst ve saygılı olması gerektiğini ifade etmiştir. Öğrencilerden B.İ.S. “Güven önemli. Benim ona onun bana güvenmesi gerek. Bu yoksa, bir şeyler oturmamış demektir." Şeklinde duygularını ifade ederken; A.S. "Güvenilir, sorumluluk sahibi, empati yapan." şeklinde duygularını ifade etmiştir. 


\section{İletişim Teması}

Çalışma grubunda yer alan öğrencilere "iletişim" olgusu çerçevesinde yöneltilen sorulara öğrencilerin verdiği yanitlar ve frekansları Tablo 5'de yer almaktadır.

Tablo 5

İletişim Olgusuna İlişkin Sorular ve Öğrenci Yanıtları

\begin{tabular}{lccc}
\hline Sorular & Cevaplar & $f$ & $\%$ \\
\hline & Ben veririm. & 8 & 65 \\
Okula geldiğinde ilk selam veren sen mi olursun yoksa birilerinin & Beklerim. & 2 & 17 \\
sana selam vermesini mi beklersin? & Selam vermiyoruz. & 1 & 8 \\
& Değişiyor. & 1 & 8 \\
Yeni bir ortama girdiğinde o ortamdaki yeni arkadaşlar ile gidip & Tanışırım. & 5 & 42 \\
tanışır mısın? Yoksa gelip seninle tanışmalarını mı beklersin? & Beklerim. & 5 & 40 \\
Arkadaşına karşı nazik misin? Övgü ve iltifat eder misin? & Bazen tanışırım, bazen beklerim. & 2 & 17 \\
Hoşlandığın konular hakkında arkadaşınla konuşur musun? & Evet. & 12 & 100 \\
& Evet konuşurum. & 11 & 91 \\
\hline
\end{tabular}

Araştırmada yer alan öğrencilere, “Arkadaşına karşı nazik misin? Övgü ve iltifat eder misin?” sorusu sorulduğunda öğrencilerin tamamı arkadaşlarına karşı nazik olduklarını, övgüde bulunduklarını belirtmişlerdir. Öğrencilerden K.U. bu soru ile ilgili düşüncelerini, "Çok. Mesela H. deneme sınavında kötü bir sonuç yapmışstı depresyona girmiş̧ti, ben de çok üzüldüm. Hep yanındaydım. Başarıll olduğu zamanlarda mutlu olup tebrik ederim." şeklinde ifade etmiştir.

"Yeni bir ortama girdiğinde o ortamdaki yeni arkadaşlar ile gidip tanışır mısın? Yoksa gelip seninle tanışmalarını $\mathrm{m}$ beklersin?" sorusu sorulduğunda öğrencilerden beş tanesi yeni bir ortama girdiğinde kendisinin tanıştığını vurgularken, diğer beş öğrenci de gelip tanışmalarını beklediğini vurgulamıştır. Geriye kalan iki öğrenci ise bazen tanışıp, bazen beklediklerini vurgulamışlardır. Verilen cevaplardan yola çıkarak özel yetenekli öğrencilerin tanışmak ve beklemek durumunda eşit davrandıkları görülmektedir. Öğrencilerden A.G soruyu "Tanışmak isterim. Onlar gelirse tanışırım. Biraz çekinirim herhalde." şeklinde cevaplarken, A.C.G. ise "Biraz çekinirim onların benimle tanışmasını beklerim." şeklinde cevaplamıştır.

\section{Yardım Teması}

Çalışma grubunda yer alan öğrencilere "yardım" olgusu çerçevesinde yöneltilen sorulara Öğrencilerin verdiği yanitlar ve frekansları Tablo 6'da yer almaktadır.

Tablo 6

Yardım Olgusuna İlişkin Sorular ve Öğrenci Yanıtları

\begin{tabular}{lccc}
\hline Sorular & Cevaplar & $f$ & $\%$ \\
\hline Eğer bir kişi seni rahatsız ederse, arkadaşların sana yardımcı olur mu? & Evet olur. & 11 & 91 \\
Bir arkadaşının keyifsiz olduğunu gördüğünde nesi olduğunu sorar mısın? & Hayır olmaz. & 1 & 8 \\
& Evet sorarım. & 12 & 100 \\
Eğer öğle yemeğini unutursan, arkadaşların seninle yemeklerini paylaşırlar mı? & Evet paylaşırlar. & 8 & 66 \\
& Hayır paylaşmazlar. & 3 & 25 \\
Arkadaşlarının sorunlarıyla ilgilenir misin? & Evet ilgilenirim. & 12 & 100 \\
\hline
\end{tabular}

Araştırmada yer alan öğrencilere, "Eğer bir kişi seni rahatsız ederse, arkadaşların sana yardımcı olur mu?" sorusu sorulduğunda öğrencilerin çoğunluğu arkadaşlarının kendisine yardımcı olduğunu belirtmiştir. Diğerlerinden farklı olarak sadece bir öğrenci yardımcı olmadıklarını vurgulamıştır. Nedeni sorulduğunda "bilmiyorum, kendileri bilir ama ben olsam yardımcı olurdum" yanıtını vermiştir. 
“Bir arkadaşının keyifsiz olduğunu gördüğünde nesi olduğunu sorar mısın?” sorusuna öğrencilerin tamamı arkadaşının keyifsiz olduğunda nesi olduğunu sorduğunu belirtmiştir. Öğrencilerden G.Ü., bu soru ile ilgili düşüncelerini “Evet sorarım. Çok özel bir şeyse anlatmaz. Çok da özel değilse anlatabilir. ” şeklinde ifade etmiştir.

Verilen cevaplardan yola çıkarak özel yetenekli öğrencilerin, arkadaşlarının sorunlarıyla ilgilendikleri görülmektedir. Öğrencilerden K.U. düşüncelerini “ $H$. 'in satranç turnuvası vardı. Ben ona çok destek oldum, çok stresliydi. Sakin ol, kendini kontrol et, kafanı hiç dă̆ıtma diyerek yanında oldum.” şeklinde ifade ederken; G.Ü. düşüncelerini "Evet ilgilenirim. Bir arkadaşım okula çok üzgün gelmişti ve o gün bana sorunlarını anlattı. Birlikte sorunlarına nasıl çözüm bulacă̆ımızı düşündük.” şeklinde ifade etmiştir.

\section{Bağlılık Teması}

Çalışma grubunda yer alan öğrencilere "bağlılık" olgusu çerçevesinde yöneltilen sorulara Öğrencilerin verdiği yanıtlar ve frekansları Tablo 7'de yer almaktadır.

Tablo 7

Bă̆lllık Olgusuna İlişkin Sorular ve Öğrenci Yanıtları

\begin{tabular}{|c|c|c|c|}
\hline Sorular & Cevaplar & $f$ & $\%$ \\
\hline Arkadaşların tarafından sevilir misin? & $\begin{array}{l}\text { Evet. Sevilirim. } \\
\text { Emin değilim. }\end{array}$ & $\begin{array}{c}10 \\
2\end{array}$ & $\begin{array}{l}83 \\
17\end{array}$ \\
\hline Arkadaşlarının düşüncelerine önem verir misin? & Evet, önem veririm. & 12 & 100 \\
\hline Arkadaşlarının en çok hangi yönünü seversin? & $\begin{array}{c}\text { Güvenilir olmaları. } \\
\text { Yardımsever olmaları. } \\
\text { Arkadaş canlısı olmaları. } \\
\text { Etkili iletişim kurabilmeleri. } \\
\text { Düşünerek hareket etmeleri. } \\
\text { Oyun oynamaları. } \\
\text { Ders çalışmaları }\end{array}$ & $\begin{array}{l}3 \\
2 \\
2 \\
1 \\
1 \\
1 \\
1\end{array}$ & $\begin{array}{c}25 \\
17 \\
17 \\
8 \\
8 \\
8 \\
8\end{array}$ \\
\hline Arkadaşlarına saygı duyar mısın? & Evet, saygı duyarım. & 11 & 91 \\
\hline Arkadaşların sana ilgi gösterir mi? & $\begin{array}{l}\text { Evet, ilgi gösterirler. } \\
\text { Herkese gösterdikleri kadar ilgi gösterirler. }\end{array}$ & $\begin{array}{c}11 \\
1\end{array}$ & $\begin{array}{c}91 \\
8\end{array}$ \\
\hline $\begin{array}{l}\text { Arkadaşlarınızla birbirinize olan sevginizden } \\
\text { bahseder misiniz? Örnek verebilir misin? }\end{array}$ & $\begin{array}{l}\text { Evet, birlikte vakit geçiririz. } \\
\text { Evet, birbirimize'.....'diye hitap ederiz. } \\
\text { Pek bahsetmem. } \\
\text { Onlara zarar gelse üzülürüm. }\end{array}$ & $\begin{array}{l}6 \\
4 \\
1 \\
1\end{array}$ & $\begin{array}{c}50 \\
33 \\
8 \\
8\end{array}$ \\
\hline $\begin{array}{l}\text { Paraya ihtiyacın olsa çekinmeden } \\
\text { arkadaşlarından ister misin? }\end{array}$ & $\begin{array}{l}\text { Evet isterim. } \\
\text { İstemem, hayır. }\end{array}$ & $\begin{array}{c}10 \\
2\end{array}$ & $\begin{array}{l}83 \\
17\end{array}$ \\
\hline $\begin{array}{l}\text { En yakın arkadaşın ve sen ikinizden birini } \\
\text { rahatsı edecek bir şey yaparsanız, bunun } \\
\text { üstesinden nasıl gelirsiniz? }\end{array}$ & $\begin{array}{l}\text { Konuşarak düzeltmeye çalışırız. } \\
\text { Biraz ayrı kalırız. } \\
\text { Özür dileriz. }\end{array}$ & $\begin{array}{l}9 \\
1 \\
1\end{array}$ & $\begin{array}{l}75 \\
8 \\
8\end{array}$ \\
\hline $\begin{array}{l}\text { Yapmak istemediğin halde arkadaşlarını } \\
\text { kırmamak için yaptığın şeyler ya da katıldığın } \\
\text { etkinlikler oluyor mu? }\end{array}$ & $\begin{array}{l}\text { Evet, oluyor, yaparım. } \\
\text { Hiç olmadı ama olursa yaparım. } \\
\text { Olmuyor, yapmam. }\end{array}$ & $\begin{array}{l}7 \\
2 \\
3\end{array}$ & $\begin{array}{l}58 \\
17 \\
25\end{array}$ \\
\hline
\end{tabular}

Araştırmada yer alan öğrencilere “Arkadaşların tarafından sevilir misin?” sorusu sorulduğunda öğrencilerin çoğunluğu sevildiğini düşünmektedir. İki öğrenci bundan emin olmadıklarını ifade etmişlerdir. Öğrencilerden G.Ü. "Evet sevilirim. Yani sevilmeseydim benimle arkadaşlık kurmazlardl ve bana iyi davranmazlardl” diyerek görüşlerini belirtmişstir.

“Arkadaşlarınızla birbirinize olan sevginizden bahseder misiniz?” sorusuna özel yetenekli öğrencilerin birlikte vakit geçirme ve sevgi arasında bir ilişki kurdukları görülmektedir. Öğrencilerden altısı soru yöneltildiğinde birlikteyken yaptıklarından bahsetmiştir. Öğrencilerden dördü arkadaşlarıyla birbirlerine 
hitaplarını belirtmişlerdir. Öğrencilerden H.S. "K. seni çok seviyorum direk demiyorum. Ama sınıfta sorduklarında en çok K. 'ı seviyorum diyorum” demiştir. Öğrencilerden A.S. “Onlara zarar gelse üzülüyorum.” cevabını vererek araştırmaya katılan diğer öğrencilerden farklı bir cevap vermiştir.

\section{Güven Teması}

Çalışma grubunda yer alan öğrencilere "güven” olgusu çerçevesinde yöneltilen sorulara öğrencilerin verdiği yanıtlar ve frekansları Tablo 8'de yer almaktadır.

Tablo 8

Güven Olgusuna İlişkin Sorular ve Öğrenci Yanıtları

\begin{tabular}{lccc}
\hline Sorular & Cevaplar & $f$ & $\%$ \\
\hline & Hayır, paylaşmam. & 10 & 83 \\
Arkadaşının sana verdiği sırrı başkalarıyla paylaşır mısın? & Anne ve babama söylerim. & 1 & 8 \\
& Büyük bir şey değilse paylaşırım. & 1 & 8 \\
& Evet, var. & 12 & 100 \\
Güvendiğin bir arkadaşın var mı? Neden ona & Yalan söylemiyor. & 3 & 25 \\
güveniyorsun? & Her zaman yanımda. & 4 & 33 \\
& Ortak yönlerimiz çok. & 3 & 25 \\
& Beni seviyor. & 1 & 8 \\
Annenin ve babanın seni anlamadığı ve anladığı konular & İyi bir arkadaş kendi halinde. & 1 & 8 \\
olduğunda arkadaşlarınla paylaşır mısın? & Hayır, paylaşmam. & 6 & 50 \\
& Evet, paylaşırım. & 4 & 33 \\
Hiç kimseye söyleyemeyeceğin şeyleri, söyleyebileceğin & Ara sira. & 2 & 17 \\
arkadaşların var mı? & Evet var. & 10 & 83 \\
\hline
\end{tabular}

Araştırmada yer alan öğrencilere "Arkadaşının sana verdiği sırrı başkalarıyla paylaşır mısın? Neden?” sorusu sorulduğunda öğrencilerin kendileriyle paylaşılan sırları başkalarıyla paylaşmayacaklarını söyledikleri görülmektedir. Öğrencilerden E.K. "Çok büyük bir şey değilse, mesela sınavdan 93 almışsa diğer arkadaşlarıma söylerim. Ama çok özelse söylemem." diyerek arkadaşlarından farklı bir cevap vermiştir. Bir öğrenci de yalnızca anne ve babasıyla paylaşacağını söylemiştir. Öğrencilerden H.S.C. "Hayır paylaşmam. Ama kötü bir şey yapacaksa, büyüklerime söylerim.” diye cevap vermiştir.

Araştırmada yer alan öğrencilere yöneltilen "Annenin ve babanın seni anlamadığı ve anladığı konular olduğunda arkadaşlarınla paylaşır mısın?" sorusuna özel yetenekli öğrenciler çoğunlukla hayır cevabını vermişlerdir. Dört öğrenci evet paylaşırım şeklinde yanıt vermiştir. B.İ.S, "Evet. Belki de haksızımdır paylaşırım fikir alırım.” şeklinde yanıt vermiştir. İki öğrenci de ara sıra ve çok az cevaplarını vermiştir.

\section{Özdeşim Teması}

Çalışma grubunda yer alan öğrencilere “özdeşim” olgusu çerçevesinde yöneltilen sorulara öğrencilerin verdiği yanıtlar ve frekansları Tablo 9'da yer almaktadır.

Tablo 9

Özdeşim Olgusuna İlişkin Sorular ve Öğrenci Yanttları

\begin{tabular}{lccc}
\hline Sorular & Cevaplar & $f$ & $\%$ \\
\hline & Evet, isterdim. & 12 & 100 \\
& Evet çünkü güzelim. & 2 & 17 \\
Sen arkadaşlarının yerinde olsaydın seninle & Evet çünkü çalışkanım. & 4 & 33 \\
arkadaş olmak ister miydin? Neden? & Evet çünkü kavga etmiyorum uyumluyum. & 3 & 25 \\
& Evet çünkü eğlenceliyim. & 1 & 8 \\
& Evet çünkü farkliyım. & 1 & 8 \\
\hline
\end{tabular}


Tablo 9 (devam)

\begin{tabular}{lccc}
\hline Sorular & Cevaplar & $f$ & $\%$ \\
\hline & İyi bir arkadaşım. & 7 & 58 \\
Sence sen nasıl bir arkadaşsın? & Güzel bir arkadaşım. & 1 & 8 \\
& Konuşkan eğlenmeyi seven. & 1 & 8 \\
& Her zaman arkadaşlarının yanında olan. & 1 & 8 \\
& Arkadaş canlısı bir arkadaşım. & 1 & 8 \\
En iyi arkadaşın gibi olmak ister misin? & Hayır istemem. & 6 & 50 \\
& Evet isterim. & 4 & 33 \\
& Bazı yönleriyle evet. & 2 & 17 \\
Arkadaşının başarısı sana ne hissettirir? & Mutluluk. & 7 & 58 \\
& Güzel hissettirir. & 1 & 8 \\
& Gipta ederim. & 1 & 8 \\
Bir işi başardığında arkadaşın senin için & Gurur duyarım. & 1 & 8 \\
mutlu olur mu? & Beni azimlendirir. & 1 & 8 \\
& Bir şey hissettirmez. & 1 & 8 \\
& Evet, olur. & 10 & 83 \\
& Hayır olmaz. & 1 & 8 \\
\hline
\end{tabular}

Araştırmada yer alan öğrencilere "Sen arkadaşlarının yerinde olsaydın seninle arkadaş olmak ister miydin? Neden?” sorusu sorulduğunda özel yetenekli öğrencilerin hepsi kendileriyle arkadaş olmak isteyeceklerini belirtmişlerdir. Öğrencilerden A.A.L "İsterdim. Biraz tereddüt ederdim. Çünkü ilk etapta çok yakın davranamıyorum." diyerek diğer arkadaşlarından farklı bir yanıt vermiştir. Öğrencilerden ikisi beğenileceklerini düşündüklerinden, dördü çalışkan ve başarılı olduklarından, üçü kavga etmeyip uyumlu olduklarından, biri eğlenceli olduğu için, biri de farklı olduğu için kendisiyle arkadaş olmak isteyeceğini belirtmiştir. Örnek.

"Arkadaşının başarısı sana ne hissettirir?" sorusuna öğrencilerden biri dışında tamamı olumlu duygulardan bahsetmiştir. H.S. isimli öğrenci "Bir şey hissettirmez. Aferin der geçerim." diyerek tarafsız bir duygu belirtmiştir. Öğrencilerden yedisi mutlu hissedeceğini, birer öğrenci de güzel hissederim, gıpta ederim, gurur duyarım diye cevap vermişlerdir. Öğrencilerden A.S. "Beni azimlendirir." diye cevap vermiştir.

"Bir işi başardığında arkadaşın senin için mutlu olur mu?” sorusu sorulduğunda öğrencilerden biri dışında tamamı olumlu duygulardan bahsetmiștir. E.K. "Bilmiyorum. Bir keresinde yüksek bir not almıştım, o zaman bence arkadaşım mutlu olmamıştı. Bence hayır." Yanıtını vermiştir. Bir öğrenci "Bazı arkadaşlarım mutlu olur." cevabını vermiştir. Araştırmaya katılan öğrencilerden 10'u evet, mutlu olur cevabını vermiştir. H.S. isimli öğrenci "Evet olur. Ama K. tenisi çok seviyor ve eğer turnuva da ben birinci olsaydım istemezdi. Çünkü birinci olmayı o çok istiyordu.” şeklinde cevap vermiştir.

\section{Sadakat Teması}

Çalışma grubunda yer alan öğrencilere "sadakat" olgusu çerçevesinde yöneltilen sorulara öğrencilerin verdiği yanıtlar ve frekansları Tablo 10'da yer almaktadır.

Tablo 10

Sadakat Olgusuna İlişkin Sorular ve Öğrenci Yanıtları

\begin{tabular}{|c|c|c|c|}
\hline Sorular & Cevaplar & $f$ & $\%$ \\
\hline \multirow{3}{*}{$\begin{array}{l}\text { Arkadaşın seni uygun olmayan bir davranışa } \\
\text { sürüklese, onunla olmaya devam eder misin? }\end{array}$} & Devam ederim. & 4 & 33 \\
\hline & Hayır devam etmem. & 7 & 58 \\
\hline & Yanlışlıkla yaptıysa ederim. & 1 & 8 \\
\hline \multirow{3}{*}{$\begin{array}{l}\text { Her zaman arkadaşının tarafını tutar, onları kötü söz } \\
\text { ve hakaretlere karşı korur musun? }\end{array}$} & Evet. & 6 & 50 \\
\hline & Haklıysa evet. & 5 & 42 \\
\hline & Hayır. & 1 & 8 \\
\hline
\end{tabular}


Tablo 10 (devam)

\begin{tabular}{lccc}
\hline Sorular & Cevaplar & $f$ & $\%$ \\
\hline & Üzülürüm. & 6 & 50 \\
Sevdiğin bir arkadaşın uzağa taşınırsa ne hissedersin? & Kötü hissederim. & 4 & 33 \\
& Özlem duyarım. & 1 & 8 \\
& Onunla görüş̧meye çalışırım. & 1 & 8 \\
Arkadaşlarının zayıf yönleriyle alay eder misin? & Hayır, etmem. & 8 & 66 \\
& Çok nadir ederim. & 2 & 17 \\
\hline
\end{tabular}

Araştırmada yer alan öğrencilere "Arkadaşın seni uygun olmayan bir davranışa sürüklese, onunla olmaya devam eder misin? sorusu sorulduğunda özel yetenekli öğrenciler uygun olmayan bir davranışla karşılaştıklarında çoğunlukla arkadaşlıklarını sürdürmeyeceklerini söylemişlerdir. "Hayır" cevabını veren öğrenci sayısı yedidir. Dört öğrenci devam ederim şeklinde yanıt vermiştir. Bir öğrenci ise yanlışlıkla olmuşsa devam ederim şeklinde cevap vermiştir. A.L. isimli öğrenci "Şiddet olmadı̆̆ sürece. Uygun olmayan bir davranışsa yapar gibi yapıp onu da vaz geçiririm." şeklinde cevap vermiştir.

"Her zaman arkadaşının tarafını tutar, onları kötü söz ve hakaretlere karşı korur musun?” sorusuna öğrencilerin çoğunluğu arkadaşlarının tarafını tuttuklarını belirtirken yine bir kısmı eğer haklıysa tuttuğunu belirtmiştir. Bir öğrenci de haklı ya da haksız da olsa tutmadığını belirtmiştir. Öğrencilerden G.Ü. duygularını "Ĕ̆er arkadaşım haklıysa onun tarafını tutarım. Haksızsa haklının tarafını tutarım. Ama onu kötü sözlere karşı korurum." şeklinde ifade ederken; R.N.K. "Hayır çünkü bazen onlar da haksızlık yapıyorlar" şeklinde ifade etmiştir.

"Sevdiğin bir arkadaşın uzağa taşınırsa ne hissedersin?" sorusu sorulduğunda, öğrencilerin üzüntü duyacakları görülmüştür. Öğrencilerden A.C.G. ise "Onunla telefonla görüşmeye çalışırım. Elimden gelirse yanına giderim.” cevabını vermiştir.

\section{Tartıșma ve Sonuç}

Özel yetenekli öğrencilerin “birliktelik” temasına yönelik yanıtlarına bakıldığında, bu öğrencilerin çoğunun okul çıkışı arkadaşlarının evine gittikleri ve bu sebepten dolayı mutlu oldukları görülmektedir. Özel yetenekli öğrenciler boş zamanlarında arkadaşlarıyla görüştüklerini, arkadaşlarıyla yapabileceği eğlenceli şeyler düşündüklerini, ayrıca arkadaşlarıyla birlikteyken kendilerini mutlu hissettiklerini belirtmişlerdir. Alan yazında yer alan bazı araştırmalar özel yetenekli çocukların arkadaş edinebilmek adına bir çıkış noktası bulamadığı için yalnız kaldıklarını (Smutny, 2001; Webb, Amend, Webb, \& Goerss, 2013) belirtmektedir. Ancak bu araştırma, alan yazında yer alan araştırmaların bulgularından farklı yönde bir bulguyla sonuçlanmıştır.

Araştırmaya katılan öğrencilerden çoğunluğu iyi bir arkadaşta olması gereken en önemli özelliğin güven duygusu olduğunu ifade etmiştir. Gross (2002), özel yetenekli çocukların arkadaşlık kavramıyla ilgili bakış açılarının yaşlarına ve gelişim dönemlerine göre farklı evrelerden geçtiğini belirtmiştir. İlk evre olan "oyun arkadaşı" evresinde çocuklar için önemli olan oyun oynayabilecek bir arkadaşa sahip olmasıdır. İkinci evre "konuşabilecek kişi evresidir". Bu evrede sadece birlikte oyun oynamak yeterli gelmez. Benzer ilgi alanları bulunan, arkadaş arayışı içine girerler. Üçüncü evre olan “yardımcı ve destekleyici” evresinde ise arkadaş, yardım edebilecek ve cesaretlendirecek kişidir. "Yakınlık ve empati” evresinde arkadaşlık, iki taraflı bir hal alır. Yardım etme, anlayış gösterme gittikçe iki taraf arasında derinleşir. Son evre olan "güven" evresinde ise kendisini, her koşulda kabul edebilecek, anlayabilecek, bir nevi güvenli bir limana ihtiyaç duymaktadır. Bu evrede tüm düşüncelerini paylaşabileceği, maskesiz davranabileceği kişiyi arkadaş olarak görür. Evrelerden de anlaşıldığı gibi Gross'a (2012) göre "güven” arkadaşlıkta gelinen en son noktadır. Gross (2012)'un araştırmasına göre aynı yaşlardaki özel yetenekli çocuklar güvenebilecekleri arkadaşlar seçerken, normal gelişim gösteren akranları oyun arkadaşı aramaktadırlar. Bu araştırmadan elde edilen sonuçlara göre de çalışma grubunda yer alan çocukların çoğunluğu iyi bir arkadaşta aradığı özellikler arasında "güven” duygusuna vurgu yapmışlardır. Dolayısıyla 
Gross'un (2012) çalışmasına paralel olarak arkadaşlık ilişkilerinde arkadaş seçimi yaparken güven duygusunun önemli bir yere sahip olduğu söylenebilir.

$\mathrm{Bu}$ araștırmada özel yetenekli öğrencilerin yarısı hem arkadaşları ile birlikte vakit geçirmekten hem de yalnız vakit geçirmekten hoşlandıklarını belirtmiştir. Alan yazına bakıldığında özellikle dışa dönük özel yetenekli çocukların bulundukları arkadaş gruplarında popülerken içe dönük özel yetenekli çocukların genellikle yalnız kalmayı tercih ettikleri ve kendi ilgi alanlarına yönelik vakit geçirdikleri belirtilmektedir (Webb vd., 2013). Diğer taraftan bunu tersi yönünde sonuçlanan araştırma bulgularına da alan yazında rastlamak mümkündür. Erdem'in (2013) yürüttüğü araştırmanın bulgularına göre özel yetenekli çocukların akranları ile birlikte dışarıda vakit geçirme oranı \%82'dir. Dışarıda birlikte yaptıkları aktivitelerin başlıcaları ise; sohbet etmek, sinemaya gitmek, ders çalışmak ve spor yapmak olarak sıralanmıştır. Bu araştırmada ise çalışma grubunda yer alan özel yetenekli çocukların \%50'si akranlarının evlerine gittiklerini, \%66'sı boş zamanlarında görüştüklerini ve \%75'i ise birlikte yapabilecek eğlenceli şeyler bulduklarını ifade etmişlerdir. Bu araştırmaların bulguları özel yetenekli öğrencilerin akranları ile okul dışında da görüşme ve birlikte aktiviteler gerçekleştirme oranlarının yüksek olduğunu göstermektedir. Bu da özel yetenekli çocukların sosyal yeterliklerinin iyi düzeyde olduğuna işaret etmektedir. Nitekim özel yetenekli çocukların sosyal yeterliklerinin normal gelişim gösteren çocuklardan daha yüksek olduğunu ortaya koyan araştırma bulguları bu araştırma tarafından da desteklenmektedir (Akpolat, 2017)

Özel yetenekli öğrencilerin “çatışma” olgusuna yönelik yanıtlarına bakıldığında, bu öğrencilerin çoğunun kontrollü davranarak, arkadaşı kendine hata bile yapsa hiddete kapılıp kötü ve düşüncesiz sözler söylemediklerini ifade etmişlerdir. Öğrencilerin çoğunluğu arkadaşlarıyla kavga ettiklerini, tartıştıklarını belirtirken, araştırmaya katılan ö̆grencilerin tamamı arkadaşlarıyla kavga ettiklerinde ve hatalı olduklarında özür dilediklerini belirtmiştir. Çağlar (2004) özel yetenekli öğrencilerin kendi kişisel hatalarını görebildiklerini ve düzeltebildiklerini ifade etmektedir. Dolaysıyla eldeki araştırmanın bulguları literatürle paralellik göstermektedir.

Özel yetenekli öğrencilerin “yakınlık” olgusuna yönelik yanıtlarına bakıldığında, bu öğrencilerin çoğunluğunun arkadaşının fikirlerini önemsedikleri görülmektedir. Nitekim Çağlar (2004) özel yetenekli ögrencilerin başkalarının fikirlerine ve hislerine saygılı olduklarını belirtmiş̧tir. Bu araştırmada ayrıca özel yetenekli öğrencilerin tamamı arkadaşlarına karşı nazik olduğunu ve övgüde bulunduğunu, çoğunluğu hoşlandıkları konularla ilgili arkadaşlarıyla konuştuklarını, arkadaşları etraflarında yokken onları düşündüklerini, arkadaşları onlar için özel bir şey yaptığında mutlu olduklarını belirtmişlerdir. Özel yetenekli çocukların arkadaşlık kurabilme ve beraber zaman geçirebilmeleri için entelektüel seviyeleri yakın olduğu kadar ilgi alanlarının da ortak olması gerekmektedir. Özel yetenekli çocuğun gözünden bakıldığında bir arkadaş, onunla konudan konuya atlayabilmeli, yeni bilgileri ve ilgilerini paylaşmalı, öğrendiklerini öğretebilmeli ve tüm bunları coşkuyla yapabilmelidir (Webb vd., 2013). Bu araştırmada iyi bir arkadaşta aradıkları özellik kapsamında empati kurabilmeye vurgu yapılmıştır. Benzer bir bulgu da Fornia ve Frame'in (2001) araştırma bulgularında karşımıza çıkmaktadır. Bu bulgulara göre özel yetenekli çocukların normal gelişim gösteren akranlarına oranla arkadaşlık ilişkilerinde daha fazla empati kurabildikleri belirlenmiştir. Özel yetenekli çocukların göze çarpan en belirgin özellikleri akranlarına kıyasla daha hızlı öğrenme kabiliyetleri ve zihinsel aktivitelerinin üst düzey olmasıdır. Buna ek olarak kendini doğru şekilde ifade etme, karşısındaki bireylerin düşüncelerini ve duygularını anlayabilme, onların psikolojik durumları hakkında fikir yürütebilme gibi beceriler ile dil ve iletişim becerilerinde de oldukça iyi düzeydedirler. Özel yetenekli çocukların bu özellikleri, onları daha empatik düşünmelerini ve başkalarının fikir ve tercihlerine saygı duymalarını kolaylaştırmaktadır. Empati kurabilme kabiliyeti, bu çocuklarda bu nedenle daha güçlü olabilmektedir (Girgin \& Şahin, 2019).

Özel yetenekli öğrencilerin “İletişim” olgusuna yönelik yanıtlarına bakıldığında, bu öğrencilerin yarısının okula geldiklerinde ilk selam veren kişi oldukları görülmektedir. Öğrencilerden beş tanesi yeni bir ortama girdiğinde kendisinin tanıştığını vurgularken, diğer beş öğrenci de karşı tarafın gelip tanışmalarını beklediğini belirtmiştir. Mevcut literatür, özel yetenekli çocukların iletişim sürecini başlatma ve yürütme konusunda bilişsel yeteneklerini etkili bir şekilde kullanabildiklerini ve böylelikle bu becerilerini sosyal ilişkiler geliştirme ve yürütmede kullandıklarını vurgulamaktadır (Clark, 2002). Özel yetenekli çocukların akranları tarafından 
dışlandıklarını, iletişimlerinin zayıf olduğunu ve yalnızlığa itildiklerini gösteren araştırmalar da olmasına rağmen (Boland \& Gross, 2007; Helt, 2008), bu çocukların özellikle kendi bilişsel düzeylerindeki akranları ile beraberken etkili iletişim kurabildiklerini ve uyum sağladıklarını gösteren araştırmalar daha fazla sayıdadır (Kaya, Erdoğan, \& Çağlayan, 2014; Oğurlu, 2010; Saranlı \& Metin, 2012). Üstün bilişsel potansiyele ve özel yeteneklere sahip çocukların akranlarına göre daha erken ve daha ileri düzeyde gelişmiş dil becerilerine sahip oldukları ve sahip oldukları dil becerileri sayesinde çocukların arkadaşlarıyla daha etkin bir şekilde iletişimi başlatabildikleri, sürdürebildikleri ve bundan doyum elde edebildikleri araştırma bulguları ile desteklenmektedir (Clark, 2002; Erdem, 2013; Ergin, 2004; Robinson, 2008; Ruf, 2009; Shechtman \& Silektor, 2012; Sternberg, 1997).

Özel yetenekli öğrencilerin "yardım” olgusuna yönelik yanıtlarına göre bu öğrencilerin çoğunluğu eğer bir kişi tarafından rahatsız edilirse arkadaşlarının kendisine yardımcı olduğunu, arkadaşları keyifsiz olduğunda onlarla ilgilendiklerini, arkadaşlarının onlarla yemeklerini paylaştığını belirtmişlerdir. Yine araştırmaya katılan öğrencilerin tamamı arkadaşlarının sorunlarıyla ilgilendiklerini belirtmişlerdir. Mevcut literatürde bu bulguya paralel olarak özel yetenekli çocukların dünyayı ilgilendiren problemlere ve diğer insanların duygularına karşı yoğun ilgi duyduklarını ve normalin üstünde merhamet duygusu taşıdıklarını belirtilmektedir (Çağlar, 2004). Özel yetenekli öğrenciler, duygularını yoğun ve derin bir şekilde yaşamaktadır. Başkaları için endişelenme, yüksek sağduyu, haksızlık, adaletsizlik ve ikiyüzlülük karşısında hassasiyet, empati, sorumluluk ve güvenilirlik duygusu ile kendi kendini sorgulama yönleri oldukça gelişmiş̧tir (Dabrowski, 1979; 1994) Gündüz (2010) tarafından yürütülen araştırmanın bulgularına göre; değerler eğitimi çerçevesinde özel yetenekli bireylerin önemsedikleri değerler belirlenmiştir. Buna göre özel yetenekli bireyler adil bir Dünya beklentisi içerisindedir. Bütün kötülüklerin ortadan kaldırılmasını hayal etmekte ve Dünya barışını önemsemektedirler. Ayrıca bireyler arasında gelir farklılıklarını yok etme hedefi, fakir ve yoksulları zenginleştirme isteği en güçlü değerler arasında yer almaktadır.

Özel yetenekli öğrencilerin "bağll11k" olgusuna yönelik yanıtları öğrencilerin çoğunluğunun arkadaşlık kurdukları kişiler tarafından sevildiklerine dair düşüncelerinin yüksek olduğunu, arkadaşlık kurdukları kişilerin düşüncelerine önem verdiklerini göstermektedir. Ciğerci'nin (2006) yürütttüğü araştırmanın bulguları da bu bulguya paralellik göstermektedir. Araştırmada özel yetenekli öğrencilerin normal yaşıtlarına göre başkalarının kendileri hakkında olumlu düşüncelere sahip olduğu düşüncesinin daha yaygın olduğunu bulmuştur. Ayrıca özel yetenekli öğrencilerin arkadaşlarını güvenilir buldukları ve bu yönlerini sevdikleri, arkadaşlarına saygı duydukları, arkadaşlarından ilgi gördükleri, öğrencilerin birlikte vakit geçirme ve sevgi arasında ilişki kurdukları görülmektedir. Araştırmada özel yetenekli öğrencilerin kendileri ve arkadaşlarıyla ilgili olumlu duygulardan bahsettikleri görülmektedir. Uysal'ın (2014) çalışmasında da öğrencilerin çoğunluğunun, paraya ihtiyaçları olduğunda yakın arkadaşlarından isteyebilecekleri ve ortak bir problemleri olduğunda konuşarak çözmeye çalışacakları belirtilmektedir. Arkadaşları uzak bir yere taşındığında üzüntü duyacakları, yapmak istemedikleri halde arkadaşları için bazı etkinliklere katılabilecekleri belirtilmektedir. Araştırmanın bu bulgusuyla ilgili olarak Oğurlu ve Yaman (2010), özel yetenekli çocukların duygusal özellikleri ve ihtiyaçlarının normal zekâya sahip akranlarına göre daha yoğun olduğunu belirtmişlerdir. Bazı araştırmacılar, gelişmiş öğrenmeye neden olan beyin yapısının daha yüksek duygusallığa da yol açtı̆̆ını savunmaktadırlar (Porter, 1999). Bu durum özel yetenekli çocuklardaki yoğun duygusallığı açıklayabilir. Yoğun duygusal yapıya sahip özel yetenekli öğrencilerin yapmak istemedikleri halde arkadaşları için bazı etkinliklere katılma nedenleri bu duygusal yapıyla ilgili olabilir.

Özel yetenekli öğrencilerin "güven” olgusuna yönelik yanıtları, öğrencilerin çoğunluğunun kendileriyle paylaşılan sırları başkalarıyla paylaşmayacaklarını göstermektedir. Ayrıca özel yetenekli öğrencilerin güvendikleri arkadaşları olduğu ve kendileri ile ilgili özel sırları paylaşabilecekleri arkadaşları olduğu görülmüştür. Güven duygusunun araştırmaya katılan özel yetenekli çocuklar için önemli olduğu görülmektedir. Araştırmaya katılan özel yetenekli öğrencilerin çoğunluğu arkadaşlarına güven duyma nedeni olarak "her zaman yanımda" yanıtını vermiştir. Strip ve Hirch'e (2000) göre de özel yetenekli çocukların yaşamlarında önemli kişiler arasında onlara zaman ayıran ve güvenebildikleri kişiler bulunmaktadır. Koç (2015) araştırmasında özel yetenekli öğrencilerin karşısındakine güven duyduğunda daha iyi iletişim kurabileceklerini ifade etmiştir. Aynı araştırmada özel 
yetenekli çocukların bazıları yeni arkadaşlara güvenmediklerini de söylemişlerdir. Bu durum özel yetenekli çocukların yeni bir arkadaşla tanıştığında güvenmediklerini fakat zamanla güvendikçe de daha iyi iletişim kurabildiklerini göstermektedir.

Özel yetenekli öğrencilerin “özdeşim” olgusuna yönelik yanıtları, öğrencilerin çoğunluğunun kendileriyle arkadaş olmak isteyeceklerini ve iyi bir arkadaş olduklarını düşündüklerini göstermektedir. Buna göre özel yetenekli çocuklar arkadaşlık ve arkadaşlık etme konularında kendilerine güvenmektedirler. Kuzgun’a (1972) göre kişinin kendisi ile ilgili düşünceleri olumlu kavramlar içeriyorsa, o kişi yüksek benlik saygısına sahiptir ve kişinin kendisi hakkındaki güçlü ve olumlu duyguları diğerleri ile kuracağı iletişimlerinde olumlu etki sağlamaktadır. Yine araştırmaya katılan öğrencilerin yarısının en iyi arkadaşlarına benzemek istemediklerini diğer yarısının ise isterim ve bazı yönleriyle isterim gibi ara cevaplar verdikleri görülmektedir. Özdeşim kurma, bireyin herhangi bir sosyal grup içerisinde bulunurken iletişimde bulunduğu kişi veya kişilere duyduğu hayranlık, yakınlık hissi, uyum sağlama ve taklit etme becerisi olarak ifade edilebilir (Mangır \& Baran, 1990). Douthitt (1992) yaptığ araştırmada özel yetenekli ve normal gelişim gösteren 296 çocukla çalışmış, zeka puanları ile uyum puanları arasında yüksek bir ilişki olduğunu, özel yetenekli çocukların normal gelişim gösteren yaşıtlarına kıyasla daha yüksek oranda uyumlu davranışlar gösterdiklerini bulmuştur. Özel yetenekli çocuklar da normal gelişim gösteren çocuklar gibi sosyalleşme ve arkadaşlık kurma ihtiyacı duymaktadırlar. Saranlı ve Metin (2012) özel yetenekli çocukların zeka bölümleri arttıkça normal davranış kalıplarından uzaklaştıkları ve var olan üstünlüklerinin onları çevreye yabancılaşma ve depresyon gibi sorunlara itebileceğini belirtmiştir. Bu görüş alan yazınındaki farklılıkları açıklamak açısından anlamlıdır.

Özel yetenekli çocuk ve ergenlerin akranlarıyla ortak sosyal beklentileri olmasına karşın, arkadaşlık ve yakın ilişkilerde yetenekli olmalarından kaynaklanan problemler ortaya çıkabilmektedir. Özel yetenekli çocukların diğerlerinin önüne geçip başarılı olmalarını sağlayan özellikleri, aynı zamanda onların akran ve arkadaş gruplarından, sosyal ortamlardan dışlanmalarına, kıskanılarak yalnız bırakılmalarına da sebep olabilmektedir (Helt, 2008). Ancak bu araştırmanın bulguları bu durumun tam tersini işaret etmektedir. Özel yetenekli çocuklar arkadaşlarının başarısından mutluluk duymakta, kendi başarılarının da arkadaşlarının mutlu edeceğini düşünmektedirler. Özel yetenekli öğrencilerin arkadaşlarının zayıf yönleriyle alay etmediklerini ifade ettikleri görülmüştür. Başka bir ifade ile özel yetenekli çocuklar kendi arkadaşlık ilişkileri hakkında olumlu görüşe sahiptir. Fakat Helt'in (2008) araştırma bulgularına göre özel yetenekli çocuklar kendi arkadaşlık ilişkileri hakkında daha olumsuz görüşe sahiptir. Bu araştırmada olduğu gibi Helt (2008) tarafından yürütülen araştırmada da özel yetenekli çocukların kendi görüşlerine dayalı olarak sonuçlar elde edilmiştir. Ancak Helt (2008) araştırmasında 9-18 yaş grubu ile çalışmıştır. Bu araştırmada ise daha küçük yaş grubu (7-13 yaş) ile çalışılmıştır. Arkadaşlık ilişskileri yaş dönemlerinde farklılaşan bir yapıya sahiptir. Özellikle ergenlik dönemi, tüm gelişim dönemleri içerisinde stresli, zorlu ve çatışmalarla geçen bir dönemdir. Bu dönemde kimlik karmaşası, aile ve yakın çevreyle sorun yaşama, akran ilişskilerinde tutarsız ve sorunlu davranışlar gösterme, kaygılı, öfkeli, depresif veya isyankâr davranışlar bu dönemin sık görülen özellikleridir (Köse, 2015). Tüm bu özellikler arkadaşlık ilişkilerini de etkileyebilmektedir. Dolayısıyla her iki araştırma bulgusu arasındaki farklı bulguların nedeni yaş dönemlerinin farklı olması ve arkadaşlık ilişkilerinin yaş dönemlerinde farklı seyretmesi ile ilgili olabilir.

Özel yetenekli öğrencilerin "Sadakat” olgusuna yönelik yanıtlarına bakıldığında, bulgular öğrencilerin uygun olmayan bir davranışla karşılaştıklarında çoğunlukla arkadaşlıklarını sürdürmeyeceklerini göstermektedir. Mükemmeliyetçi özellikler gösteren özel yetenekli çocuklar, kendileri veya etraflarındaki kişiler hata yaptıklarında bundan çok rahatsız olurlar (Saranlı \& Metin, 2012). Bu araştırmanın bulguları bu görüşü desteklemektedir. Sak da (2016) zeka düzeyinin kişilerin dünyaya bakış açısı ve sosyal ilişkileri kısmen etkilediğini bu nedenle özel yetenekli öğrencilerin arkadaş seçiminde daha dikkatli olduklarını belirtmiştir. Hatch ve Johnson (1988), özel yetenekli çocuklarla yürüttüğü çalışmada, eş zamanlı olmayan gelişimden kaynaklanan sürekli olarak akranlarına patronluk taslama/onlara karışma ve kendi yaşıtlarından oluşan gruplara girmekte zorlanma gibi davranışlar gözlemlemiştir. 
Sonuç olarak; bu araştırmada özel yetenekli çocukların kendi arkadaşlık ilişkilerine yönelik görüşleri incelenmiştir. İlgili literatürde her ne kadar farklı bulgularla karşılaşılsa da bu araştırma bulgularına göre özel yetenekli çocukların kendilerini arkadaşlık ilişkilerinde yeterli ve iyi düzeyde gördükleri söylenebilir. Ancak bu araştırma yalnızca özel yetenekli çocukların kendi görüşlerine dayalı olarak belirlenmiş olup, bu durum bu araştırmanın bir sınırlılığıdır. Özel yetenekli bireylerin kendi sahip olduğu özellikler hakkında "tam olarak" objektif değerlendirme olanaklı olamayacağından, daha net sonuçlar elde edebilmek için ileri araştırmalarda özel yetenekli öğrencilerin kendi arkadaşlık ilişkilerine yönelik görüşlerine ek olarak akranlarının da "özel yetenekli öğrencinin arkadaşlık ilişkilerine" yönelik görüşleri alınarak iki grup arasında karşılaştırma yapılabilir. Ayrıca bu araştırmanın bulgularından hareketle özel yetenekli çocukların eğitim aldığı okullarda onların sadece genel kültür ve genel yetenek alanlarında değil; aynı zamanda duyuşsal alanlarda ve sosyal becerilerde desteklenmeleri önerilebilir. 


\section{Kaynaklar}

Akarsu, F. (2001). Üstün yetenekli çocuklar [Gifted Children]. Ankara: Eduser Yayınları.

Akpolat, A. H. (2017). Üstün yetenekli çocukların sosyal yeterliliklerinin sını içerisindeki sosyometrik statülerine göre incelenmesi [Examining the social competencies of gifted children according to their sociometric status in the classroom] (Yüksek Lisans Tezi). http://docs.neu.edu.tr/library/6673294270.pdf adresinden edinilmiştir.

Atik, Z. E., Çok, F., Esen-Çoban, A., Doğan, T., \& Güney-Karaman, N. (2014). Akran ilişkileri ölçeğinin Türkçeye uyarlanması. Geçerlik ve güvenirlik çalışması [Adaptation of the peer relations scale to Turkish. Validity and reliability study]. Kuram ve Uygulamada Ĕgitim, 14(2), 433-446.

Bainbridge, C. (2011) Social and emotional problems affecting gifted children. http://giftedkids.about.com/od/socialemotionalissues/a/gtproblems adresinden edinilmiştir.

Bloomquist, M. L., \& Schnell, S.V. (2002). Helping children with aggresion and conduct problems. New York: The Guilford Press.

Boland, C. M., \& Gross, M. U. M. (2007). Counseling highly gifted children and adolescents. In S. Mendaglio \& J. S. Peterson (Eds.), Models of counseling gifted children, adolescents, and young adults (pp. 153-199). USA: Prufrock Press.

Büyükbayraktar, Ç. (2011). Üniversite ögrencilerinde mükemmeliyetçilik ve öfke ilişkisi [The relationship between perfectionism and anger among university students] (Yüksek lisans tezi). Yükseköğretim Kurulu Ulusal Tez Merkezinden edinilmiştir. (Tez Numarası: 278657)

Burton, C. B. (2001). Children's peer relationships. https://www.ericdigests.org/pre-923/peer.htm adresinden erişilmiştir.

Ciğerci, Z. C. (2006). Üstün yetenekli olan ve olmayan ergenlerde benlik saygısı, başkaları tarafindan algılanma ve psikolojik belirtilerin karşılaştırllması [Self-esteem, perception by others and comparison of psychological symptoms in gifted and non-gifted adolescents] (Yüksek lisans tezi). Yükseköğretim Kurulu Ulusal Tez Merkezinden edinilmiştir. (Tez Numarası: 186799)

Clark, B. (2002). Growing up gifted: Developing the potential of children at school and at home. USA, New Jersey: Merill Prentice Hall Press.

Cotien, L., \& Manion, L. (1994). Research methods in education (4th ed.). London: Routlenge.

Creswell, J. W. (2013). Nitel araştırma yöntemleri: Beş yaklaşıma göre nitel araştırma ve araştırma deseni [Qualitative research methods: Qualitative research and research design according to five approaches]. Bütün, B. \& Beşir, S. B. (Çev. Eds.). Ankara: Siyasal Kitabevi.

Çağlar, D. (2004). Üstün yetenekli çocuklar seçilmiş makaleler kitabı [Gifted children selected articles book]. İstanbul: Çocuk Vakfı Yayınları.

Çetinkaya, Ç. (2014). The effect of gifted students' creative problem solving program on creative thinking. Social and Behavioral Sciences, 116(2014), 3722-3726.

Dabrowski, K. (1979). The heroism of sensitivity. (E. Hyzy-Strzelecka, Trans.). Advanced Development, 6(1), $87-$ 92.

Dağlıŏlu, H. E. (2010). Üstün yetenekli çocukların eğitiminde öğretmen yeterlikleri ve özellikleri [Teacher competencies and features in the education of gifted children]. Milli Eğitim Dergisi, 39(186), 72-84.

Davis, G. A., \& Rimm, S. B. (2004). Education of the gifted and talented. Boston, MA: Pearson Education Press.

Delikara, İ. E. (2000). Ergenlerin akran ilişkileri ve suç kabul edilen davranışlar arasındaki ilişkinin incelenmesi [Examining the relationship between adolescents' peer relationships and criminal behavior] (Yüksek lisans tezi). Yükseköğretim Kurulu Ulusal Tez Merkezinden edinilmiştir. (Tez Numarası: 94573) 
Dixon, F. A., Lapsley, D. K., \& Hanchon, T. A (2004). An empirical typology of perfectionism in gifted adolescents. Gifted Child Quarterly, 48(2), 95-106.

Dodge, D. T., \& Bickart, T. S. (1998). Preschool for parents. Washington: Teaching Strategies.

Douthitt, V. C. (1992). A comparison of adaptive behaviour in gifted and nongifted children. Roeper Review, 14(3), 149-15.

Enns, M. W., Cox, B., \& Clara, I. (2002). Adaptive and maladaptive perfectionism: Developmental origins and association with depression proneness. Personality and Individual Differences, 33(6), 921-35.

Erdem, B. (2013). Bilim ve sanat merkezine devam eden üstün zekâlı ve özel yetenekli çocukların sosyalleşme koşulları (Batı Akdeniz Bölgesi örneği) [Socialization conditions of gifted and special talent children continuing to science and art center (Example of Western Mediterranean Region)] (Yüksek lisans tezi). Yükseköğretim Kurulu Ulusal Tez Merkezinden edinilmiştir. (Tez Numarası: 369052)

Ergin, H. (2004). Zekâ düzeyinin “İletişim Becerileri Eğitim Programı”ndan yararlanma düzeyine etkisi [The effect of intelligence level on the level of benefiting from the "Communication Skills Training Program”]. Kulaksızoğlu, A. (Ed.), 1. Üstün Yetenekli Çocuklar Kongresi Üstün Yetenekli Çocuklar Bildiriler Kitabı içinde (ss.107-119). İstanbul: Çocuk Vakfı Yayınları.

Erigüç, G., Şener, T., \& Eriş, H. (2013). İletişim becerilerinin değerlendirilmesi: Bir meslek yüksekokulu ögrencileri örneği [Evaluation of communication skills: An example of a vocational school students]. Hacettepe Sağlık İdaresi Dergisi, 16(1), 45-65.

Fergusson, D. M., Lianne, J. W., \& Horwood, L. J. (1999). Childhood peer relationships problems and young people's involvement with deviant pers in adolescence. Journal of Abnormal Child Psychology, 27(5), 357-369.

Fiedler, E. D. (1993). Square pegs in round holes: Gifted kids who don’t fit in. Understanding Our Gifted, 5, 1114.

Fornia, G. L., \& Frame M. W. (2001). The social and emotional needs of gifted children: Implications for family counseling. The Family Journal, 9, 384-390.

Girgin, D., \& Şahin, Ç. (2019). Üstün yetenekli öğrencilerin "Ben ......olsaydım” etkinliğine yönelik görüşleri [Opinions of gifted students on the effectiveness "If I were ..."]. Gazi Eğitim Bilimleri Dergisi, 5(Özel Say1), 177-195. doi: 10.30855/gjes.2019.os.01.010

Gross, M. U. (2002). Musings: Gifted children and the gift of friendship. Open Space Communications, 14(3), 2729.

Gross, M. U. (2012). "Play partner" or "Sure shelter": What gifted children look for in friendship. SENG Newsletter, 2(2), 1-3.

Gülay, H. (2009). Okul öncesi dönemde akran ilişkileri [Peer relations in preschool period]. Ankara: Pegem Yayıncilik.

Gülay, H. (2010). Okul öncesi dönemde akran ilişkileri [Peer relations in preschool period]. Balıkesir Üniversitesi Sosyal Bilimler Enstitüsü Dergisi, 12(22), 82-93.

Gündüz, T. (2010). Üstün zekâlı çocuklarda ahlâk gelişimi ve eğitimi [Moral development and education in gifted children]. İlahiyat Fakültesi Dergisi, 1(1), 157-177.

Gür., Ç. (2011, April). Üstün yetenekli çocukların karşılaştığ sosyal ve duygusal problemler ve bu problemlerin çözümüne ilişkin öneriler: arkadaş edinme sorunu, alay edilme, anksiyete-endişeler ve aşırı mükemmelliyetçilik üzerine bir çalışma [Social and emotional problems faced by gifted children and suggestions for the solution of these problems: A study on the problem of making friends, mocking, anxiety-anxiety and extreme perfectionism]. 2nd International Conference on New Trends in Education and Their Implications, Antalya-Turkey. http://www.iconte.org/FileUpload/ks59689/File/228.cagla.gur.pdf adresinden erişilmiştir. 
Hatch, J., \& Johnson, L. G. (1988, November). Guiding the social development of gifted and talented preschoolers. Paper presented at the Annual Conference of the National Association for the Education of Young Children, Anaheim, CA.

Heiman, T. (2000a). Quality and quantity of friendship: Students' and teachers' perceptions. School Psychology International, 21(3), 265-280.

Heiman, T. (2000b). Friendship quality among children in three educational settings. Journal of Intellectual \& Developmental Disability, 25(1), 1-12.

Helt, C. (2008). The role of $I Q$ and gender in the social-emotional functioning of adolescents (Doctoral dissertation). Retrieved from ProQuest Information \& Learning. (2009-99170-022)

Hepler, J. B. (1997). Social development of children: The role of peers. Social Work in Education, 19(4), $242-256$.

Hewitt, P. L., Caelian, C. F., Flett, G. L., Sherry, S. B., Collins, L., \& Flynn, C. A. (2001). Perfectionism in children: Associations with depression, anxiety and anger. Personality and Individual Differences, 32(6), 152-61.

Hortaçsu, N. (1997). Insan ilişkileri [Human relationship] (2. baskı). Ankara: İmge KitabeviYayınları.

Hortaçsu, N. (2002). Çocuklukta ilişkiler: Ana-baba, kardeş ve arkadaşlar [Relationships in childhood: Parents, siblings and friends]. Ankara: İmge Yayınevi.

Kaner, S. (1998). Akran İlişkileri Ölçeği ve Akran Sapması Ölçeği geliştirme çalışması [Peer Relations Scale and Peer Deviation Scale development study]. Ankara Üniversitesi Eğitim Bilimleri Fakültesi Özel Eğitim Bölümü. Proje No: 98-04-00-01, 1998.

Karakuş, F. (2010). Üstün yetenekli çocukların anne babalarının karşılaştıkları güçlükler [Difficulties faced by parents of gifted children]. Mersin Üniversitesi Eğitim Fakültesi Dergisi, 6(1), 127-144.

Karasar, N. (1995). Bilimsel araştırma yöntemi: Kavramlar, ilkeler ve teknikler [Scientific research method: Concepts, principles and techniques]. Ankara: Sim Matbaası.

Kaya, F., Erdoğan, R., \& Çağlayan, Y. (2014) Üstün zekalı ve yetenekli öğrencilerin okul yaşam kaliteleri ve arkadaşlık iliş̧kilerinin karşılaştırılması [Comparison of gifted and talented students' school quality of life and friendship]. Türk Üstün Zeka ve Eğitim Dergisi, 4(2), 107-125.

Kawamura, K. Y., Frost, R. O., \& Harmatz, M. (2002). The relationship of perceived parenting styles to perfectionism. Personality and Individual Differences, 32(2), 317-27.

Kearney, K. (1996). Highly gifted children: In full inclusion classrooms. Retrived from http://members.aol.com/discanner/hgfull.html

Kerr, B. A. (1985). Smart girls, gifted women: Special guidance concerns. Roeper Review, 8(1), 30-33.

Kline, B. A., \& Meckstroth, E. A. (1985). Understanding and encouraging the exceptionally gifted. Roeper Review, $8(1), 24-30$.

Koç, İ. (2015). The remarks of gifted students attending science and art center about communication skills. Journal of Gifted Education Research, 1(3), 39-53.

Koçal, Z. D, Kanar, E., Ermis, S., \& Pınar, K. (2009, Mart). Bilim ve sanat merkezine devam eden üstün yetenekli ögrencilerin temel ihtiyaçlarl: Amasya örneği [Basic needs of gifted students attending the science and art center: Amasya example]. Ulusal Üstün Yetenekli Çocuklar Kongresi'nde sunulmuş sözlü bildiri, Eskişehir, Türkiye.

Köse, N. (2015). Ergenlerde akran ilişkilerinin mutluluk düzeyine etkisi [The effect of peer relationships on happiness level in adolescents]. İönü Üniversitesi Eğitim Bilimleri Enstitüsü Dergisi, 2(4), 1-6. 
Kuzgun, Y. (1972). Anne baba tutumlarının bireyin kendini gerçekleştirme düzeyine etkisi [The effect of parenting attitudes on the self-actualization level of the individual] (Doktora Tezi). Hacettepe Üniversitesi, Ankara.

Ladd, G. W., Kochenderfer, B. J., \& Coleman, C. C. (1996). Friendship quality as a predictor of young children's early school adjustment. Child Development, 67(3), 1103-1118.

Levent, F. (2011). Üstün yetenekli çocukların hakları [Rights of gifted children]. İstanbul: Çocuk Vakfı Yayınları.

Lovecky, D. V. (1993). The quest for meaning: Counseling issues with gifted children and adolescents. In L. K. Silverman (Ed.), Counseling the gifted and talented (pp. 29-50). Denver: Love Publishing Company.

Mangır, M., \& Baran, G. (1990). Çocukta rol değişimi ve cinsel kimliğin kazanılması [Role change and sexual identity in child]. Eğitim ve Bilim Dergisi, 76(14), 66-72.

Masden, C. A., Leung, O. N., Shore, B. M., Schneider, B. H., \& Udvari, S. J. (2015). Social-perspective coordination and gifted adolescents' friendship quality. High Ability Studies, 26(1), 3-38. doi: 10.1080/13598139.2015.1028613.

Miles, M. B., \& Huberman A. M. (1984). Qualitative data analysis: A sourcebook of new methods. USA: Sage Publications.

Nail, J. M., \& Evans, J. G. (1997). The emotional adjustment of gifted adolescents: A view of global functioning. Roeper Review, 20(1), 18-21.

Neihart, M. (1999). Impact of giftedness on psychological well-being. Roeper Review, 22(1), 123-127.

Neihart, M. (1999). The impact of giftedness on psychological well being. https://positivedisintegration.com/Neihart1999.pdf adresinden erişilmiştir.

Oğurlu, Ü., \& Yaman, Y. (2010). Üstün zekâl1/yetenekli çocuklar ve iletişim [Gifted/talented children and communication]. Pamukkale Üniversitesi Ĕ̈itim Fakültesi Dergisi, 28(11), 213-223.

Patton, M. Q. (2002). Qualitative evaluation and research methods (3rd ed.). Thousand Oaks, CA: Sage

Peterson, J., Duncan, N., \& Canady, K. A. (2009). Longitudinal study of negative life events, stress, and school experiences of gifted youth. Gifted Child Quarterly, 53(1), 34-49.

Plucker, J. A., \& Levy, J. J. (2001). The downside of being talented. American Psychologist, 56(1), 75-76.

Porter, L. (1999). Gifted young children: A guide for teachers and parents (2nd ed.). Buckingham, United Kingdom: Open University Press.

Robinson, N. M. (2008). The Social World of Gifted Children and youth. In S. I. Pfeiffer (Ed.), Handbook of giftedness in children: Psychoeducational theory, research, and best practices (pp. 33-51). New York, NY: Springer.

Ruf, D. (2009). Five levels of gifted: School issues and education a loptions. Scottsdale, AZ: Great Potential Press.

Sağlam, F. N. (2011). Maslow ve ihtiyaçlar hiyerarşisi kuramı. http://www.psikiyatrivehayat.com/maslow.htm adresinden edinilmiştir

Sak, U. (2016). Üstün zekâlılar: Özellikleri, tanılanmalarl, eğitimleri [Gifted: Features, diagnoses, training]. Ankara: Vize yayıncilık.

Saranlı, A. G. (2017). Eş zamanlı olmayan gelişimin üstün yetenekli çocuklardaki görünümü üzerine bir örnek olay çalışması [A case study on the manifestation of asynchronous development in gifted children asynchronous development in gifted children]. Ankara Üniversitesi Ĕ̈itim Bilimleri Fakültesi Özel Ĕ̈itim Dergisi, 18(1), 89-108. doi: 10.21565/ozelegitimdergisi.300060 
Saranlı, A., \& Metin, N. (2012). Üstün yetenekli çocuklarda görülen sosyal-duygusal sorunlar [Social-emotional problems observed in gifted children]. Ankara University Journal of Faculty of Educational Sciences, 45(1), 139-163.

Seggie, F. N., \& Bayyurt, Y. (2015). Nitel araştırma: Yöntem, teknik, analiz ve yaklaşımları [Qualitative research: Methods, techniques, analysis and approaches]. Ankara: An1 Yayınc1lık.

Shechtman, Z., \& Silektor, A. (2012). Social competencies and difficulties of gifted children compared to nongifted peers. Roeper Review, 34(1), 63-72. doi: 10.1080/02783193.2012.627555

Shure, M. B., \& Spivack, G. (1980). Interpersonal problem solving as a mediator of behavioral adjustment in preschool and kindergarten children. Journal of Applied Developmental Psychology, 1(1), 29-44.

Shure, M. B., \& Spivack, G. (1982) Interpersonal problem-solving in young children: A cognitive approach to prevention. American Journal of Community Psychology, 10(3), 341-356.

Shure, M. B. (2001). I can problem solve (ICPS): An interpersonal cognitive problem-solving program (2nd. ed.). Illinois: Research Press.

Smith, J. A., Flowers, P., \& Larkin, M. (2009). Interpretative phenomenological analysis: Theory, method and research. Thousand Oaks, CA: Sage.

Smutny, J. F. (2001). Stand up for your gifted child. Canada: Free Spirit Publishing.

Sternberg, R. J. (1997). Successful intelligence. New York, Plume.

Strip, C. A., \& Hirsch, G. (2000). Helping gifted children soar: A practical guide for parents and teachers. Arizona Book Publishing Association.

Türnüklü, A. (2000). Eğitim bilim araştırmalarında etkin olarak kullanılabilecek nitel bir araştırma tekniği: Görüşme [A qualitative research technique that can be used effectively in educational science research: Interview]. Kuram ve Uygulamada Ĕ̈itim Yönetimi, 24(24), 543-559.

Uysal, R. (2014). The predictive roles of social safeness and flourishing on problematic Facebook use. South African Journal of Psychology, 45(2), 182-193.doi: 10.1177/0081246314560010

Vasta, R., Haith, M. M., \& Miller S. C. (1992). Child psychology. New York: Wiley.

Yıldırım, A., \& Şimşek H. (2006). Sosyal bilimlerde nitel araştırma yöntemleri [Qualitative research methods in the social sciences]. Ankara: Seçkin Yayınları.

Yoo, J. E., \& Moon, S. M. (2006). Counseling needs of gifted students: An analysis of intake forms at a university based counseling center. Gifted Child Quarterly, 50(1), 52-61.

Webb, J. T. (1994). Nurturing social emotional development of gifted children. ERIC Digest E527https://files.eric.ed.gov/fulltext/ED372554.pdf adresinden edinilmiştir.

Webb, J., Amend, E., Webb, N., \& Goerss, J. (2013). Misdiagnose van hoogbegaafden: Handreikingen voor passend hulp [Misdiagnosis of the Gifted: Guides for appropriate help]. Assen: Koninkelijkevan Gorcum.

Winner, E. (1996). Gifted children. USA: Basic Books. 


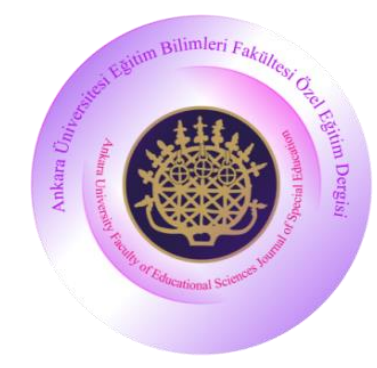

RESEARCH

\title{
Ankara University Faculty of Educational Sciences Journal of Special Education
}

Year: 2021, Volume: 22, No: 1, Page No: 113-145

doi: 10.21565/ozelegitimdergisi.621484

Received Date:18.09.19

Accepted Date: 10.09 .20

OnlineFirst: 17.09.20

\section{The Perceptions of the Gifted Children Regarding Their Friendship Relations}

\author{
Fidan Özbey-Gökçe ${ }^{\text {iD* }}$ \\ Düzce University
}

\author{
Hadiye Ellibeş-Cerrah \\ Ministry of National Education
}

\author{
Şükran Arpaz-Ünsal \\ Ministry of National Education
}

\begin{abstract}
This qualitative study aims to identify the gifted children's perceptions about their friendship relations. The participants were 12 gifted students living in three cities (Düzce, Bolu and Samsun) in Turkey. The semi-structured interview forms were utilized in data collection. A total of nine themes including cohesion, conflict, intimacy, communication, assistance, attachment, trust, identification and loyalty were identified. The findings revealed that the children often visited their friends in their houses to spend time together. They enjoyed this although they liked spending time alone as well. The "trust" was the most important personality trait of a good friend for the participants. They also cared about their friends' opinions and ideas as well as their problems. Their friends' achievements made them happy, and vice versa. The findings were discussed within the scope of previous literature. Further research is warranted to draw more reliable conclusions on this subject.
\end{abstract}

Keywords: Peer, friendship relations, gifted children, friend, peer relations.

\section{Recommended Citation}

Özbey-Gökçe, F., Ellibeş-Cerrah, H., \& Arpaz-Ünsal Ş. (2021). The perceptions of the gifted children regarding their friendship relations. Ankara University Faculty of Educational Sciences Journal of Special Education, 22(1), 113-145. doi: 10.21565/ozelegitimdergisi.621484

\footnotetext{
*Corresponding Author: Assist. Prof., E-mail: fidanozbey@ duzce.edu.tr, https://orcid.org/0000-0001-6600-3931

**Teacher, E-mail: hadiye55@ hotmail.com, https://orcid.org/0000-0003-2933-4859

***Teacher, E-mail: aytenarpaz@hotmail.com, https://orcid.org/0000-0002-9706-9711
} 
Friendship relations are of great importance in terms of children's socio-psychological development as positive relationships between peers can prepare a child for social life (Gülay, 2010). Peers guide one another while they learn the dynamics of community life and develop appropriate behavior patterns (Köse, 2015). Friendship expectations of gifted children differ from their typically-developing peers (Gross, 2002). These children are generally popular at school or within peer groups due to their characteristics. They are often easily accepted by their peers. They also have leadership qualities. However, it is observed that they may prefer loneliness as they hold different areas of interest or asynchronous development patterns.

On the other hand, some gifted children attempt to look like their friends by hiding their giftedness and dissimilar interests in order to be accepted and thus avoid loneliness. Unfortunately, some can find no way out to make friends. Therefore, they experience loneliness (Smutny, 2001).

Some of the problems experienced by gifted children in their friendships include difficulty making new friends, being ridiculed by others, having anxiety, fear and worry, and being excessively perfectionist. Such social problems faced by many gifted children in educational settings may cause them not only to want to stay away from educational settings but also to experience social problems in the future. Social-emotional problems lead to more serious problems for those children than academic failure (Gür, 2011).

It is stated that the gifted children have conflicts while communicating with their classmates due to their traits such as "perfectionism" and "selectivity in friendship". However, there are also research findings suggesting that such students do not have any problems with social cohesion. On the contrary, they can engage in a more harmonious social relationship than those with normal development. As cited in Neihart (1999), social cohesion results of the gifted children were better than the expected norms. Similarly, Nail and Evans (1997) compared 115 gifted students to 97 students with normal development in Atlanta. One of the significant results was that the gifted ones experienced less difficulty with social cohesion. Neihart (1999) also showed that the social behaviors of gifted students were generally as acceptable as those of typically-developing peers .

While the friendship relations of the gifted children are important in terms of their harmony and integration into social and educational settings, there is a limited number of studies about those children's own evaluations of themselves in terms of their friendship relations. It is believed that by revealing their perceptions regarding their own friendship relations, not only will new implications for further research be provided but also future field implementations will be carried out. Therefore, this study aims to examine the perceptions of the gifted children living in three cities (Düzce, Bolu and Samsun) in Turkey regarding their friendship relations.

The aim of this study was to examine the perceptions of gifted children regarding their own friendship relations. The research questions were given in the following: (1) How did the gifted children evaluate their friendship relations? (2) How did they evaluate the concepts of togetherness, conflict, closeness, communication, help, loyalty, trust, identification and loyalty within their friendship relations?

\section{Method}

\section{Research Model}

In this qualitative research, the phenomenology approach was adopted as the aim was to examine how people attributed meaning to their individual experiences and to focus on the nature of this interpretation (Patton, 2002).

\section{Data Collection Process}

Three main data collection techniques were used: Observation, interview and document examination (Seggie \& Bayyurt, 2015). The interview technique was utilized in this study. This can be employed through unstructured, structured and semi-structured interviews. This study was carried out through semi-structured interviews. 
Semi-structured interview technique is slightly more flexible than the structured interview technique. While using this technique, a researcher prepares an interview form that contains the questions he or she plans to ask. Depending on the flow, s/he may ask different sub-questions, encourage an interviewee to elaborate more on an answer and ask him/her to give further details. Hence, s/he may have an influence on the flow of an interview. Also, if an interviewee answers certain questions while responding to other questions during the interview, the researcher may skip those questions. The main advantage of a semi-structured interview is that it provides more systematic and comparative knowledge since it is conducted following a previously prepared interview protocol (Yıldırım \& Şimşek, 2006). Therefore, it is believed to be more appropriate for pedagogical studies.

\section{Participants}

The data were collected from gifted children living in the cities of Düzce, Bolu and Samsun. Information on the participants was given in Table 1.

Table 1

Information on the Participants

\begin{tabular}{lcccccc}
\hline Code name & Age & Class & Gender & Province & Diagnosis & Interview duration \\
\hline Z.K & 7 & 1 & Female & Bolu & Giftedness & 9 min. \\
R.N.E & 8 & 2 & Female & Bolu & Giftedness & $21 \mathrm{~min}$. \\
A.K.S & 8 & 2 & Male & Bolu & Giftedness & $18 \mathrm{~min}$. \\
E.K & 10 & 4 & Female & Samsun & Giftedness & $20 \mathrm{~min}$. \\
G.Ü & 11 & 5 & Female & Samsun & Giftedness & $23 \mathrm{~min}$. \\
K.U & 11 & 6 & Male & Samsun & Giftedness & 19 min. \\
H.S.C & 11 & 6 & Male & Samsun & Giftedness & 24 min. \\
A.C.G & 12 & 6 & Male & Düzce & Giftedness & 15 min. \\
A.A.L & 12 & 7 & Male & Düzce & Giftedness & 14 min. \\
A.S & 13 & 7 & Male & Düzce & Giftedness & 16 min. \\
B.İ.S & 13 & 7 & Male & Düzce & Giftedness & 19 min. \\
A.G & 13 & 7 & Male & Düzce & Giftedness & 18 min. \\
\hline
\end{tabular}

As seen in Table 1, the data were collected from 12 gifted students enrolled in schools in Samsun, Bolu and Düzce during 2018 - 2019 academic year. The school administration officials were contacted prior to data collection in order to inform them about the content of the study including the purpose, duration and method. Following the approval of the administration, the parents of potential participants were provided detailed information. 12 parents were sent consent forms. All of the families granted their consent for their children's participation in the study.

\section{Data Collection Tools}

A semi-structured Friendship Relations Interview Form was prepared by the researchers following literature review. During this process, two experts working in the field of special education were consulted about the form which was revised in accordance with their suggestions. It included a set of questions related to nine themes about friendship relations: "Cohesion", "conflict”, "intimacy", "communication", "assistance”, "attachment", "trust", "identification" and "loyalty".

\section{Analysis of the Data}

According to Miles and Huberman (1984), the process of qualitative data analysis includes three consecutive stages. The first stage includes "the reduction of data" that is collected through various techniques such as observations, interviews and document reviews. At this stage, the data set is processed by "selecting", "abstracting" and "transforming" data.

In this study, the data transcriptions prepared by the researchers were later categorized into the main themes. Afterwards, the data was abstracted through omission. At this stage, some themes were removed 
completely while some new themes or sub-themes were added. Accordingly, the interview transcripts were coded and categories were identified by two researchers independently. The codes and categories were compared. Mismatching codes were either eliminated or placed under appropriate categories. While creating common themes, the consensus on inter-coder reliability was considered. This was calculated using the formula "Agreement/ [Agreement + Disagreement]" as suggested by Miles and Huberman (1984). The reliability score between the coders was found to be $82 \%$.

The second stage of the analysis was the "data display". At this stage, the aim was to create certain data patterns after selecting, abstracting and transforming the data. The data set which did not yet have a clear meaning was transformed into a more comprehensible format with a pattern.

The last stage suggested by Miles and Huberman (1984) consisted of "conclusion drawing and verification". During this stage, the researcher tried to understand the meaning of the data which s/he collected. The reality hidden in the data throughout the research process was discovered and in the final stage. Nine themes were identified as a result: Cohesion, conflict, intimacy, communication, assistance, attachment, trust, identification and loyalty.

\section{Findings}

The findings related to each theme were presented in the following.

\section{The Theme of Cohesion} frequencies.

Table 2 shows the answers of the participants to the questions related to the theme of cohesion and their

Table 2

Cohesion

\begin{tabular}{lccc}
\hline Questions & Answers & Frequency & Percentage \\
\hline Do you go to your friends' house after school & Yes, I do. It makes me happy. & 6 & $50 \%$ \\
and on weekends? Do they come to your & No, I don't; they don't, either. & 4 & $33 \%$ \\
house? & We occasionally go to each other's houses. & 3 & $25 \%$ \\
& Yes, I do. & 8 & $66 \%$ \\
Do you see your friends in your free time? & No, I don't. & 3 & $25 \%$ \\
& Rarely. & 1 & $8 \%$ \\
Do you and your friends think of anything fun & Yes, we do. & 9 & $75 \%$ \\
to do? & No, we don't. & $8 \%$ & $8 \%$ \\
& Sometimes. & 1 & $50 \%$ \\
How do you feel when you're with your & I feel happy. & 6 & $8 \%$ \\
friends? & I feel joyful. & 1 & $8 \%$ \\
& Sometimes good; sometimes bad. & 1 & $17 \%$ \\
Do you like spending time alone? & I feel safe. & 1 & $8 \%$ \\
& I feel good. & 6 & $50 \%$ \\
\hline
\end{tabular}

\section{The Theme of Conflict}

Table 3 shows the answers of the participants to the questions related to the theme of conflict and their frequencies. 
Table 3

Conflict

\begin{tabular}{lccc}
\hline Questions & Answers & Frequency & Percentage \\
\hline How do you react to a mistake your friend makes towards you? Do & No, I don't. & 8 & $65 \%$ \\
you get angry and utter inconsiderate words? & Yes, I may do. & 4 & $33 \%$ \\
& Yes, I do. & 4 & $33 \%$ \\
Do you fight with your friends? & I sometimes do. & 5 & $42 \%$ \\
& No, I don't. & 3 & $33 \%$ \\
If you fight with a friend and if you are wrong, do you apologize? & Yes, I do. & 12 & $100 \%$ \\
How do you react if your friend behaves in a way making you & I warn him/her. & 11 & $91 \%$ \\
uncomfortable? & I wouldn't say anything. & 1 & $8 \%$ \\
& I warn my friend again. & 5 & $42 \%$ \\
How do you react if your friend repeats a mistake after your & I get angry. & 4 & $33 \%$ \\
warning? & I don't talk to my friend. & 1 & $8 \%$ \\
& I lose trust. & 1 & $8 \%$ \\
\hline
\end{tabular}

\section{The Theme of Intimacy} frequencies.

Table 4 shows the answers of the participants to the questions related to the theme of intimacy and their

Table 4

Intimacy

\begin{tabular}{lccc}
\hline Questions & Answers & Frequency & Percentage \\
\hline How much do your friends' ideas matter to you as & They matter a lot. & 11 & $91 \%$ \\
opposed to your own ideas and beliefs? & They matter to some extent. & 1 & $8 \%$ \\
Do you think about your friends whom you like & Yes, I do. & 11 & $91 \%$ \\
when they are not around? & I don't have time for it. & 1 & $8 \%$ \\
Do you feel happy when your friend does & Yes, I do. & 12 & $100 \%$ \\
something special for you? & Being trustworthy. & 6 & $50 \%$ \\
& Being hardworking. & 3 & $25 \%$ \\
What are the traits you look for in a good friend? & Being honest. & 1 & $8 \%$ \\
& Being respectful. & 1 & $8 \%$ \\
\hline
\end{tabular}

\section{The Theme of Communication}

Table 5 shows the answers of the participants to the questions related to the theme of communication and their frequencies.

Table 5

Communication

\begin{tabular}{|c|c|c|c|}
\hline Questions & Answers & Frequency & Percentage \\
\hline \multirow{4}{*}{$\begin{array}{l}\text { Do you say hello when you get to school first, or do } \\
\text { you expect your friends to greet you first? }\end{array}$} & I do it first. & 8 & $65 \%$ \\
\hline & I wait for others to do it. & 2 & $17 \%$ \\
\hline & We don't greet each other. & 1 & $8 \%$ \\
\hline & It depends. & 1 & $8 \%$ \\
\hline
\end{tabular}


Table 5 (continued)

\begin{tabular}{|c|c|c|c|}
\hline Questions & Answers & Frequency & Percentage \\
\hline \multirow{3}{*}{$\begin{array}{l}\text { When you're in a new environment, do you go and meet } \\
\text { new people? Or do you expect them to approach and } \\
\text { meet you? }\end{array}$} & I do. & 5 & $42 \%$ \\
\hline & I wait for others to do it. & 5 & $42 \%$ \\
\hline & $\begin{array}{l}\text { Sometimes I go and meet them, } \\
\text { sometimes I wait for them. }\end{array}$ & 2 & $17 \%$ \\
\hline Are you kind to your friends? Do you compliment them? & Yes, I do. & 12 & $100 \%$ \\
\hline \multirow{2}{*}{ Do you talk to your friends about subjects that you like? } & Yes, I do. & 11 & $91 \%$ \\
\hline & No, I don't. & 1 & $8 \%$ \\
\hline
\end{tabular}

\section{The Theme of Assistance} frequencies.

Table 6 shows the answers of the participants to the questions related to the theme of assistance and their

Table 6

\begin{tabular}{lccc} 
Assistance & & & \\
\hline Questions & Answers & Frequency & Percentage \\
\hline Do your friends help you when somebody bothers you? & Yes, they do. & 11 & $91 \%$ \\
& No, they don't. & 1 & $8 \%$ \\
When you see a friend in a bad mood, do you ask him/her what's wrong? & Yes, I do. & 12 & $100 \%$ \\
If you forget your lunch, do your friends share their meals with you? & Yes, they do. & 8 & $66 \%$ \\
& No, they don't. & 3 & $25 \%$ \\
Do you take care of your friends' problems? & Yes, Ido. & 12 & $100 \%$ \\
\hline
\end{tabular}

\section{The Theme of Attachment}

Table 7 shows the answers of the participants to the questions related to the theme of attachment and their frequencies.

Table 7

Attachment

\begin{tabular}{lccc}
\hline Questions & Answers & Frequency & Percentage \\
\hline Are you loved by your friends? & Yes, I am. & 10 & $83 \%$ \\
& I am not sure. & 2 & $17 \%$ \\
Do you care about your friends' ideas? & Yes, I do. & 12 & $100 \%$ \\
& (that) They are trustworthy. & 3 & $25 \%$ \\
& (that) They are helpful. & 2 & $17 \%$ \\
& (that) They are friendly. & 2 & $17 \%$ \\
What do you like most about your friends? & (that) They are able to & 1 & $8 \%$ \\
& communicate effectively. & 1 & $8 \%$ \\
& (that) They behave consciously. & 1 & $8 \%$ \\
Do you respect your friends? & (that) They play games. & 1 & $8 \%$ \\
& (that) They study lessons. & 11 & $91 \%$ \\
Do your friends show any interest in you? & Yes, I do. & 11 & $91 \%$ \\
& Yes, they do. & 1 & $8 \%$ \\
Do you and your friends talk about your fondness & Yes, we call each other '.....'. & 4 & $50 \%$ \\
for each other? Could you give an example? & I don't talk about it much. & 1 & $33 \%$ \\
& I feel sorry if they get hurt. & 1 & $8 \%$ \\
\hline
\end{tabular}


Table 7 (continued)

\begin{tabular}{lccc}
\hline Questions & Answers & Frequency & Percentage \\
\hline If you need money, can you ask for some from your & Yes, I can. & 10 & $83 \%$ \\
friends? & No, I can't. & 2 & $17 \%$ \\
If either you or your best friend does something & We try to negotiate to solve it. & 9 & $75 \%$ \\
that bothers the other, how do you handle the & We take a break. & 1 & $8 \%$ \\
situation? & We apologize to each other. & 1 & $8 \%$ \\
& Yes there are, and I do it. & 7 & $58 \%$ \\
$\begin{array}{l}\text { Are there activities or events that you may } \\
\text { unwillingly participate in so as not to upset your }\end{array}$ & There has never been any, but I & 2 & $17 \%$ \\
friends? & would do it. & $25 \%$ \\
& No, there aren't and I would not do & 3 & \\
\hline
\end{tabular}

\section{The Theme of Trust} frequencies.

Table 8 shows the answers of the participants to the questions related to the theme of trust and their

Table 8

Trust

\begin{tabular}{lccc}
\hline Questions & Answers & Frequency & Percentage \\
\hline & No, I don't. & $83 \%$ \\
Do you tell a friend's secret to others? & I tell my parents. & $8 \%$ \\
& I do if it is not a big deal. & 1 & $8 \%$ \\
& Yes, I do; I trust him/her & 12 & $100 \%$ \\
Do you have a friend whom you trust? If so, & because s/he doesn't lie. & 3 & $25 \%$ \\
why do you trust him/her? & because s/he is always by my side. & 4 & $33 \%$ \\
& because we have a lot in common. & 3 & $25 \%$ \\
Do you share the issues about which your & because s/he loves me. & 1 & $8 \%$ \\
parents do or do not understand you with your & S/he is a discreet and good friend. & 1 & $8 \%$ \\
friends? & No, I don't. & 6 & $50 \%$ \\
Do you have friends with whom you can & Yes, I do. & 4 & $33 \%$ \\
share your secrets that you cannot tell anyone & Sometimes. & 2 & $17 \%$ \\
else? & Yes, I do. & 10 & $83 \%$ \\
\hline
\end{tabular}

\section{The Theme of Identification}

Table 9 shows the answers of the participants to the questions related to the theme of identification and their frequencies.

Table 9

Identification

\begin{tabular}{|c|c|c|c|}
\hline Questions & Answers & Frequency & Percentage \\
\hline \multirow{6}{*}{$\begin{array}{l}\text { If you were in your friends' } \\
\text { shoes, would you make } \\
\text { friends with yourself? Why? }\end{array}$} & Yes, I would & 12 & $100 \%$ \\
\hline & because I am beautiful. & 2 & $17 \%$ \\
\hline & because I am hardworking. & 4 & $33 \%$ \\
\hline & because I don't fight. I'm adaptable & 3 & $25 \%$ \\
\hline & because I am fun. & 1 & $8 \%$ \\
\hline & because I'm different. & 1 & $8 \%$ \\
\hline
\end{tabular}


Table 9 (continued)

\begin{tabular}{lccc}
\hline Questions & Answers & Frequency & Percentage \\
\hline & A good friend. & 7 & $58 \%$ \\
How do you define yourself as & A beautiful friend. & 1 & $8 \%$ \\
a friend? & A talkative and enjoyable friend. & 1 & $8 \%$ \\
& A friend who is always there for others. & 1 & $8 \%$ \\
Would you like to resemble & An amiable friend. & 1 & $8 \%$ \\
your best friend? & No, I wouldn't. & 6 & $50 \%$ \\
& Yes, I would. & 2 & $33 \%$ \\
& In some aspects, yes I would. & 7 & $17 \%$ \\
How does a friend's & I feel happy. & 1 & $58 \%$ \\
achievement make you feel? & I feel good. & 1 & $8 \%$ \\
& I envy him/her. & 1 & $8 \%$ \\
Do your friends feel happy for & I feel proud. & 1 & $8 \%$ \\
you when you achieve & It makes me feel tenacious. & 1 & $8 \%$ \\
something? & It doesn't make me feel anything. & 10 & $83 \%$ \\
\hline
\end{tabular}

\section{The Theme of Loyalty}

Table 10 shows the answers of the participants to the questions related to the theme of loyalty and their frequencies.

Table 10

Loyalty

\begin{tabular}{lccc}
\hline Questions & Answers & Frequency & Percentage \\
\hline If a friend drags you into an inappropriate & Yes, I will. & 4 & $33 \%$ \\
behavior, will you continue your friendship & No, I won't. & 7 & $58 \%$ \\
with him/her? & I will only if s/he does that by mistake. & 1 & $8 \%$ \\
Do you always take your friend's side and & Yes, I do. & 6 & $50 \%$ \\
protect them against bad words and insults? & If s/he's right, yes I do. & 5 & $42 \%$ \\
& No, I don't. & 1 & $8 \%$ \\
How do you feel if a friend you love moves & I feel sorry. & 6 & $50 \%$ \\
away? & I feel bad. & 4 & $33 \%$ \\
& I miss him/her. & $8 \%$ \\
Do you make fun of your friends' & I try to meet him/her. & 1 & $8 \%$ \\
weaknesses? & No, I don't. & 8 & $66 \%$ \\
\hline
\end{tabular}

\section{Conclusion and Discussion}

When the responses given to the questions about the theme of cohesion by the gifted students are considered, it can be seen that most of them go to their friends' houses after school, which makes them happy. The students have also stated that they meet their friends in their free time, they can think of fun things to do together, and they feel happy when they spend time with their friends. The majority of the students have pointed out that the most important trait of a good friend is the sense of trust. According to Gross (2002), the perspectives of gifted children regarding the concept of friendship go through different phases depending on their age and developmental period. In the first phase (entitled "the play partner" phase) it is important for these children to have a friend with whom they can play games. At the second stage (entitled "people to chat with" phase), playing together is not 
enough on its own. They start looking for friends with similar interests. In the next phase, the "help and encouragement" phase, a friend is regarded as the person who can help and encourage them. In the "intimacy and empathy" phase, friendship becomes mutual. Assistance and empathy become deeper between the two parties. In the final "secure shelter" phase, these children need safe shelter that can accept and understand them under any circumstance. Taking the phases listed by Gross (2002) into consideration, it can be said that "trust" is the last point they reach in their friendship relations.

Regarding the responses about the theme of conflict, most of these students can control their actions. Even if their friend makes a mistake, they do not get angry and say bad and inconsiderate words. While most students have stated that they fight and argue with their friends, all the participants have also mentioned that they apologize if they are wrong. Similarly, Çağlar (2004) states that gifted students can notice and correct their own personal mistakes.Most of the participants have stated that they care about their friends' ideas in terms of the phenomenon of intimacy. Likewise, Çağlar (2004) puts forwards that gifted students have respect for other individuals' ideas and feelings.

As for their answers about the theme of communication, the majority of these students greet their friends first when they arrive at school. In addition, five of the students meet people when they are in a new environment, while the other five expect other people to initiate the interaction. Previous studies suggest that gifted children can effectively use their cognitive abilities to initiate and maintain communication processes, and thus they are able to use these skills to develop and continue social relationships (Clark, 2002). Although some studies indicate that those students are alienated and isolated by their peers and they have poor communication with their peers, others suggest the opposite. Such studies conclude that these children can effectively communicate and harmonize with their peers who are at the same cognitive level (Kaya, Erdoğan, \& Çağlayan, 2014; Saranlı \& Metin, 2012; Ogurlu \& Yaman 2010).

Regarding the theme of assistance, most of the students are helped by their friends if they are disturbed by somebody, they provide their friends with care when they feel upset, and their friends share their food with them. Moreover, all the participants have stated that they give attention to their friends' problems. As regards the theme of attachment, most of the students are loved by their friends and they care about their friends' opinions. In support of these findings, Ciğerci (2006) also states that it is more common for gifted students to believe that other individuals have positive opinions of these students. The students express positive feelings about themselves and their friends, as well. Similar to this study, Uysal (2014) demonstrates that the majority of students can ask their close friends to lend them some money if they need it and they try to solve their problems through negotiation. Moreover, they have mentioned that the students will be sad if their friends move to a remote location and they may participate in some activities for their friends even when they do not want to. Regarding this finding, Oğurlu and Yaman (2010) have claimed that the emotional characteristics and needs of gifted children are more intense than their peers. This may explain the reasons why gifted students unwillingly participate in some activities just for their friends.

Based on the findings about the theme of trust, it can be said that most of the participants keep their friends' secrets. These participants also have friends whom they trust and share their secrets with. Trust seems to of great importance for the participants. Most of them have stated that having friends gives them confidence. Likewise, Strip and Hirsch (2000) claim that gifted people care about those who allocate time to them.

The responses of the gifted students about the theme of identification suggest that the majority of students would make friends with themselves and they regard themselves to be a good friend. Therefore, it can be concluded that they have high self-esteem in terms of friendship and companionship. According to Kuzgun (1972), if one's self-perception contains positive concepts, it is a sign that s/he has high self-esteem and positive feelings about himself or herself, which will have a good impact while communicating with others.

The participants' responses given to the questions about the theme of loyalty indicate that encountering inappropriate behaviors usually leads them to terminate a friendship. Gifted children with perfectionism feel very 
uncomfortable when they or those around them make mistakes (Saranlı \& Metin, 2012). The findings of this study are consistent with this view, as well. Sak (2016) also notes that the level of intelligence partially affects people's outlook on the world and social relations for which gifted students may be more careful while choosing friends.

As a conclusion, this study aims at revealing the perceptions of the gifted children regarding their friendship relations. Despite different findings among previous literature, the findings of this study have shown that the gifted children consider themselves adequate and well-qualified in friendship relations. However, it is unlikely that individuals can make a completely objective evaluation of their own characteristics. Therefore, further research on the peers' perceptions regarding the gifted children's friendship relations can be conducted to draw more reliable conclusions on this subject. In addition, it is recommended that schools where gifted children receive education can support them not only in academic areas, but also in affective domain and social skills. 